\title{
Cyclic changes in messenger RNAs encoding inhibin/activin subunits in the ovary of the golden hamster (Mesocricetus auratus)
}

\author{
Koji Y Arai, Hisashi Kishi ${ }^{1}$, Satoshi Onodera ${ }^{1,2}$, Wanzhu Jin ${ }^{1}$, \\ Gen Watanabe ${ }^{1,3}$, Akira K Suzuki ${ }^{4}$, Shinji Takahashi ${ }^{5}$, \\ Toshihiko Kamada², Toshio Nishiyama and Kazuyoshi Taya ${ }^{1,3}$ \\ Department of Tissue Physiology, Tokyo University of Agriculture and Technology, Fuchu, Tokyo 183-8509, Japan \\ ${ }^{1}$ Laboratory of Veterinary Physiology, Tokyo University of Agriculture and Technology, Fuchu, Tokyo 183-8509, Japan \\ ${ }^{2}$ Laboratory of Animal Science, Tokyo University of Agriculture and Technology, Fuchu, Tokyo 183-8509, Japan \\ ${ }^{3}$ Department of Basic Veterinary Science, The United Graduate School of Veterinary Science, Gifu University, Gifu 501-1193, Japan \\ ${ }^{4}$ Air Pollutants Health Effect Team, National Institute of Environmental Studies, Ibaraki 305-0053, Japan \\ ${ }^{5}$ Ecological Effect Research Team, National Institute of Environmental Studies, Ibaraki 305-0053, Japan \\ (Requests for offprints should be addressed to K Taya; Email: taya@cc.tuat.ac.jp)
}

\begin{abstract}
To elucidate changing patterns of inhibin/activin subunit mRNAs in the ovary of the golden hamster (Mesocricetus auratus) during the oestrous cycle, inhibin/activin subunit cDNAs of this species were cloned and ribonuclease protection assay and in situ hybridization were carried out. Inhibin $\alpha$-subunit mRNA was localized in granulosa cells of primary, secondary, tertiary and atretic follicles throughout the 4-day oestrous cycle. It was also expressed in luteal cells on days 1 (oestrus), 2 (metoestrus) and 3 (dioestrus). $\beta A$-subunit mRNA was localized in granulosa cells of large secondary $(>200 \mu \mathrm{m})$ and tertiary follicles throughout the oestrous cycle. $\beta \mathrm{B}$-subunit mRNA was confined to granulosa cells of large secondary and tertiary follicles. Both $\alpha$ - and $\beta$ A-subunit mRNAs were also found in ovarian interstitial cells and theca interna cells of tertiary and atretic follicles in the evening of day 4 (pro-oestrus). A
\end{abstract}

striking increase in $\beta A$-subunit mRNA levels was also observed during the preovulatory period. The expression pattern of $\beta A$-subunit mRNA during the preovulatory period is unique and not found in other species. An i.v. injection of anti-luteinizing hormone-releasing hormone $(\mathrm{LHRH})$ serum before the LH surge abolished the expression of $\alpha$ - and $\beta A$-subunit mRNAs in ovarian interstitial cells and theca interna cells. The treatment also abolished the preovulatory increase in $\beta A$-subunit mRNA. Furthermore, administration of human chorionic gonadotrophin (hCG), which followed the injection of anti-LHRH serum, restored the expression patterns of $\alpha-$ and $\beta A-$ subunit mRNAs. The present study revealed that the golden hamster showed a unique expression pattern of $\beta A$-subunit mRNA in response to the LH surge.

Journal of Endocrinology (2005) 185, 561-575

\section{Introduction}

The reproductive cycle of the golden hamster (Mesocricetus auratus) has some unique characteristics as compared with the rat and mouse. For example, the corpus luteum in the cyclic ovary always begins to show signs of histological regression by 3 days after ovulation and almost completely vanishes by the next ovulation (Grady \& Greenwald 1968). In addition, the follicle-stimulating hormone (FSH) surge during the periovulatory period is clearly separated into two peaks in the golden hamster (Bast \& Greenwald 1974, Kishi et al. 1995) unlike the rat in which the FSH surges almost overlap (Watanabe et al. 1990).

Inhibins, which belong to the transforming growth factor- $\beta$ (TGF- $\beta$ ) superfamily, were initially isolated from ovarian follicular fluid as peptides that preferentially inhibit FSH secretion from the pituitary gland (de Jong 1988, Ying 1988). Two inhibins have been identified. Each inhibin is composed of a common $\alpha$-subunit and either a $\beta \mathrm{A}$-subunit to give rise to inhibin $\mathrm{A}$ or a $\beta \mathrm{B}$-subunit to form inhibin B (de Jong 1988, Ying 1988). On the other hand, the $\beta \mathrm{A}$ - and $\beta \mathrm{B}$-subunits of inhibin form homoand hetero-dimers termed activin $\mathrm{A}$, activin $\mathrm{AB}$, and activin B (de Jong 1988, Ying 1988). Although activins were initially isolated as gonadal peptides that stimulate FSH secretion (de Jong 1988, Ying 1988), they are now known to be multifunctional growth factors that are very important for vertebrate development and other physiological events (Mather et al. 1992, 1997, Hillier \& Miro 1993, Findlay et al. 2001). Inhibins are known to be major 
FSH-suppressing factors in the female in mammals (Rivier et al. 1986, Rivier \& Vale 1989, Culler \& Negro-Vilar 1989, Kaneko et al. 1995, Arai et al. 1996, 1997, Kishi et al. 1999, Medan et al. 2003) and are important for determining species-specific ovulation rate (Rivier \& Vale 1989, Taya et al. 1996). They are mainly expressed in granulosa cells of the ovary in adult cyclic females of various mammals, such as rats (Merchenthaler et al. 1987, Meunier et al. 1988), golden hamsters (Kishi et al. 2002), Siberian hamsters (Phodopus sungorus) (Kenny et al. 2002a,b), sheep (Engelhardt et al. 1993), pigs (Rokukawa et al. 1986), cows (Rokukawa et al. 1986), monkeys (Schwall et al. 1990) and humans (Merchenthaler et al. 1987).

Previous studies have demonstrated that expression of mRNAs encoding inhibin/activin subunits in the ovary shows noticeable changes during the rat oestrous cycle (Meunier et al. 1988, Woodruff et al. 1988, Arai et al. $2002)$, and the changing patterns of ovarian $\beta A-$ and $\beta B$-subunit mRNAs were very similar to those of plasma inhibin A and inhibin B respectively (Arai et al. 2002). Our previous data demonstrated that changing patterns of plasma inhibin A and inhibin B in the golden hamster were discordant during the oestrous cycle (Ohshima et al. 1999), as observed in the rat (Woodruff et al. 1996, Arai et al. 2002). The changing pattern of plasma inhibin B in the golden hamster was very similar to that in the rat. However, plasma concentrations of inhibin A showed a striking rise during the preovulatory period (Ohshima et al. 1999), which was not observed in rats (Woodruff et al. 1996, Arai et al. 2002), cows (Kaneko et al. 2002) and humans (Muttukrishna et al. 1994). Although these data suggest that the golden hamster ovary would show a unique changing pattern of $\beta A$-subunit mRNA during the preovulatory period, cyclic changes in levels and distribution patterns of inhibin/activin subunit mRNAs in the golden hamster ovary remain unknown. To elucidate the changing patterns of inhibin/activin subunit mRNAs in the ovary of this species, we cloned cDNAs encoding $\alpha-, \beta A-$ and $\beta \mathrm{B}$-subunits from the golden hamster ovary by rapid amplification of cDNA ends (RACE) and examined expression patterns of these mRNAs by ribonuclease protection assay and in situ hybridization during the oestrous cycle. Furthermore, we examined the effects of the preovulatory luteinizing hormone (LH) surge on inhibin/activin subunit mRNA expression by administering antiserum to LH-releasing hormone (LHRH).

\section{Materials and Methods}

\section{Animals}

Adult cyclic golden hamsters (Mesocricetus auratus; 2-3 months old) were kept under controlled temperature and lighting (lights on from 0500 to $1900 \mathrm{~h}$ ) conditions. The
Table 1 Gene-specific primers for inhibin/activin subunits

\section{Sequence}

\section{Primer}

$\alpha$-sense primer $\alpha$-antisense primer $\beta A$-sense primer 1 $\beta A$-sense primer 2 $\beta A$-antisense primer 1 $\beta A$-antisense primer 2 $\beta \mathrm{B}$-sense primer 1 $\beta B$-sense primer 2 $\beta B$-antisense primer

4-day oestrous cycle was monitored by the presence of characteristic vaginal discharge in the morning of the day of ovulation, which was designated day 1 of the oestrous cycle. Golden hamsters with at least two consecutive 4-day oestrous cycles were used in this study. The animals were treated in accordance with the Guide for the Care and Use of Laboratory Animals prepared at Tokyo University of Agriculture and Technology.

\section{Cloning of inhibin/activin subunit cDNAs by RACE}

Female golden hamsters were anaesthetized with ether and killed by decapitation. The ovaries were immediately frozen in liquid nitrogen and stored at $-80{ }^{\circ} \mathrm{C}$ until isolation of total RNA with TRIzol reagent (Invitrogen). Ovarian poly $\mathrm{A}(+)$ RNA was prepared with OligotexdT30 Super (Roche), and then 3'- and 5'-RACE were done as previously described (Arai et al. 2003). An adaptor primer (5'-GGCCACGCGTCGACTAGTAC-3') and gene-specific primers as listed in Table 1 were used. Gene-specific primers were designed by choosing the homologous DNA sequence regions between rat, mouse and human homologues of inhibin/activin subunit cDNAs, which were available from GenBank (National Centre for Biotechnology Information, National Library of Medicine, Bethesda, MD, USA). The PCR products were subcloned into pGEM-T easy vector (Promega) and subjected to sequence analysis.

\section{RNA probes}

Template cDNAs for complementary RNA probes were prepared by RT-PCR using the gene-specific primers listed in Table 1 . Template $\alpha$-subunit cDNA was amplified with $\alpha$-sense primer and $\alpha$-antisense primer. Template $\beta A$-subunit cDNA for in situ hybridization was amplified with $\beta A$-sense primer 1 and $\beta A$-antisense primer 1. Template $\beta A$-subunit cDNA for ribonuclease protection assay was prepared with $\beta \mathrm{A}$-sense primer 2 and $\beta A$-antisense primer 2 . Template $\beta B$-subunit cDNA was prepared with $\beta \mathrm{B}$-sense primer 1 and $\beta \mathrm{B}$-antisense 
primer. Amplified cDNAs were subcloned into pGEM-T easy vector (Promega). The golden hamster GAPDH cDNA clone was obtained by $3^{\prime}$-RACE using the GAPDH-sense primer, 5'-ACCACAGTCCATGCCAT CAC-3'. The 3'-RACE product was subcloned into pGEM-T easy vector. Thereafter, the GAPDH cDNA was digested with EcoRI, and the $429 \mathrm{bp}$ fragment of golden hamster GAPDH cDNA was subcloned into pBluescript II SK $(+)$ vector (Stragagene, La Jolla, CA, USA) as a template for the RNA probe. DIG-labelled complementary RNA probes were synthesized with SP6, T3 or T7 RNA polymerase using DIG RNA labelling mixture (Roche) according to the manufacturer's protocols.

\section{Ribonuclease protection assays}

Golden hamsters were killed by decapitation at $1100 \mathrm{~h}$ on days 1 (oestrus), 2 (metoestrus), 3 (dioestrus) and at 1100 and $1700 \mathrm{~h}$ on day 4 (pro-oestrus). Three animals were killed at each point. Total ovarian RNA was isolated as described above. Ribonuclease protection assays using DIG-labelled RNA probes were carried out as previously described (Arai et al. 2001, 2002). Ten micrograms total RNA were used for detecting $\alpha$-subunit mRNA; $20 \mu \mathrm{g}$ total RNA were used for detecting $\beta A$-subunit, $\beta \mathrm{B}$ subunit and GAPDH mRNAs. The latter two mRNAs were hybridized in a single tube.

\section{Preparation of ovarian sections of cyclic golden hamsters}

Animals were killed by decapitation at $1100 \mathrm{~h}$ on each day of the oestrous cycle; at 0500,1700 and $2300 \mathrm{~h}$ on day 4 ; and at $0500 \mathrm{~h}$ on day 1 . The ovaries were fixed in freshly prepared $4 \%(\mathrm{w} / \mathrm{v})$ paraformaldehyde (PFA; Sigma) in $0.01 \mathrm{M}$ PBS and embedded in paraffin. The paraffin-embedded ovaries were serially sectioned at $6 \mu \mathrm{m}$ thickness and placed on glass slides coated with 3-aminopropyltriethoxysilane. The sections were subjected to in situ hybridization for inhibin/activin subunit mRNAs or haematoxylin-eosin staining. Ovaries from at least three animals were examined at each sampling point.

\section{Effects of anti-LHRH serum and human chorionic gonadotrophin (hCG) on inhibin/activin subunit $m R N A$ expression in the ovary}

To elucidate the effects of preovulatory LH surge on expression of ovarian inhibin/activin subunit mRNAs, animals received an i.v. injection of $200 \mu \mathrm{l}$ anti-LHRH serum at $1100 \mathrm{~h}$ on day 4 followed by an i.v. injection of either 10 IU hCG (Sankyo Zoki Ltd, Tokyo, Japan) or saline at $1300 \mathrm{~h}$. This administration protocol of the antiserum was shown to block the occurrence of the LH surge (Kishi et al. 2002). At $1700 \mathrm{~h}$ on day 4, animals were killed by decapitation and ovaries were collected. Ovaries were subjected to isolation of total RNA or preparation of ovarian sections as described above.

\section{In situ hybridization}

The sections were deparaffined with xylene, and rehydrated with a graded series of ethanol, and washed with $0 \cdot 01 \mathrm{M}$ PBS for $5 \mathrm{~min}$ twice. Thereafter, the sections were treated with $0.2 \mathrm{M} \mathrm{HCl}$ for $15 \mathrm{~min}$ at $37^{\circ} \mathrm{C}$, digested with $20 \mu \mathrm{g} / \mathrm{ml}$ proteinase $\mathrm{K}$ in $0.01 \mathrm{M}$ PBS for $15 \mathrm{~min}$ at $37^{\circ} \mathrm{C}$, fixed in $4 \%$ PFA in $0.01 \mathrm{M}$ PBS for $30 \mathrm{~min}$, and treated with $0.2 \%$ glycine in $0.01 \mathrm{M}$ PBS for $5 \mathrm{~min}$. The sections were washed with $0 \cdot 01 \mathrm{M}$ PBS between treatments. Subsequently, the sections were prehybridized in hybridization buffer ( $50 \%$ deionized formamide, $0.3 \mathrm{M} \mathrm{NaCl}, 20 \mathrm{mM}$ Tris- $\mathrm{HCl}(\mathrm{pH} \mathrm{8.0),} 1 \times$ Denhardt's solution, $0.5 \mathrm{mg} / \mathrm{ml}$ Escherichia coli tRNA) for $30 \mathrm{~min}$ at $37^{\circ} \mathrm{C}$. Complementary RNA probes diluted in hybridization buffer $(1-2 \mu \mathrm{g} / \mathrm{ml})$ were denatured for 5 min at $90{ }^{\circ} \mathrm{C}$ and hybridized overnight at $50{ }^{\circ} \mathrm{C}$ under coverslips in a humidified box. After hybridization, the sections were washed in $2 \times \mathrm{SSC} / 50 \%$ formamide for $30 \mathrm{~min}$ at $50{ }^{\circ} \mathrm{C}$, treated with RNase solution $(10 \mathrm{mM}$ Tris- $\mathrm{HCl}$ (pH 8.0), $500 \mathrm{mM} \mathrm{NaCl}, 20 \mu \mathrm{g} / \mathrm{ml} \mathrm{RNaseA}$ ) for $15 \mathrm{~min}$ at $37^{\circ} \mathrm{C}$, and washed again with $1 \times \mathrm{SCC} /$ $50 \%$ formamide for $15 \mathrm{~min}$ at $50{ }^{\circ} \mathrm{C}$. Before and after the treatment with RNaseA, the sections were washed with RNase diluent for $5 \mathrm{~min}$ twice at $37^{\circ} \mathrm{C}$. Thereafter, the sections were washed in buffer $1(0.1 \mathrm{M}$ Tris- $\mathrm{HCl}$, $0 \cdot 15 \mathrm{M} \mathrm{NaCl}, \mathrm{pH} 7 \cdot 5$ ) for $5 \mathrm{~min}$, incubated with buffer 2 (buffer 1 containing 1\% blocking reagent (Roche)) for $20 \mathrm{~min}$ at $37^{\circ} \mathrm{C}$, followed by alkaline phosphataseconjugated anti-DIG immunoglobulin G (IgG; Roche) diluted with buffer $2(1: 500)$ for $1 \mathrm{~h}$ at $37^{\circ} \mathrm{C}$. After washing with buffer 1 for $5 \mathrm{~min}$ and buffer $3(0 \cdot 1 \mathrm{M}$ Tris- $\mathrm{HCl}, 0.1 \mathrm{M} \mathrm{NaCl}, 0.05 \mathrm{M} \mathrm{MgCl}_{2}, \mathrm{pH}$ 9.5) for $10 \mathrm{~min}$ at room temperature, cRNA probes were visualized using nitroblue tetrazolium salt (Roche) and 5-bromo-4-chloro-3-indolyl phosphate (Roche). The reaction was stopped in water, and the sections were mounted. For negative controls, sense strand RNA probes were used instead of complementary RNA probes.

\section{Statistical analysis}

Values are presented as means \pm S.E.M. To compare the mean values, results were subjected to an ANOVA, followed by a Student-Neuman-Keuls test. Differences were considered significant at $\mathrm{P}<0 \cdot 05$.

\section{Results}

Cloning of complementary DNAs encoding golden hamster inhibin/activin subunits and their deduced amino-acid sequences

The $5^{\prime}-$ and $3^{\prime}$-RACE products for $\alpha$-subunit revealed a $1.4 \mathrm{~kb}$ cDNA. The $\alpha$-subunit cDNA contained a 


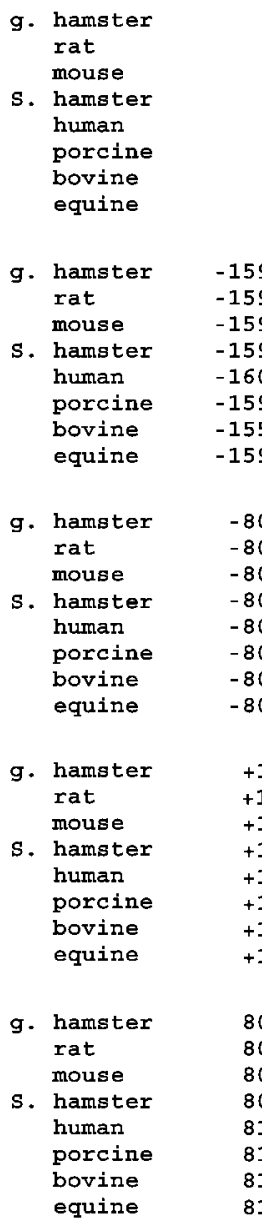

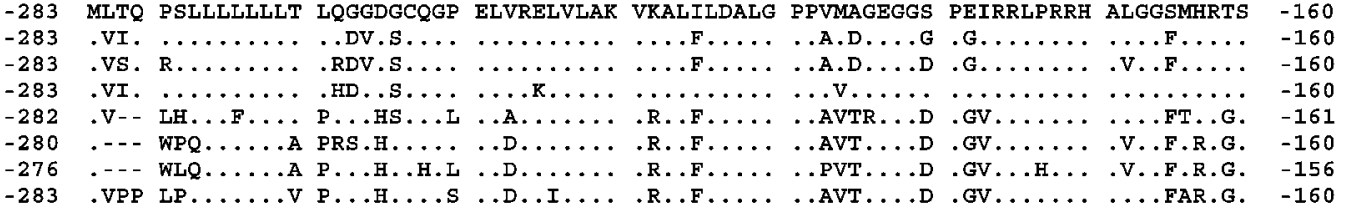

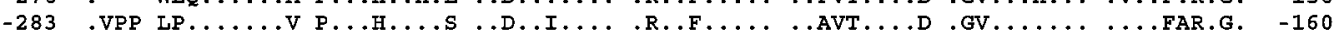

EPEEE-DVSQ VILFPATGAT CEDQPAAGGL AQEAGEGLFT YIFRPSQHMR SHQVTSAQLW FHTGLDRKNT VLSNSSGTLL -81

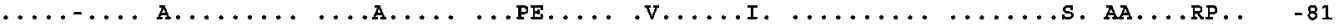

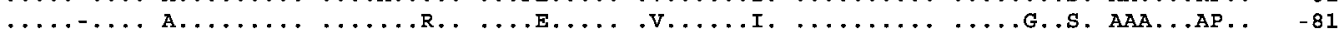

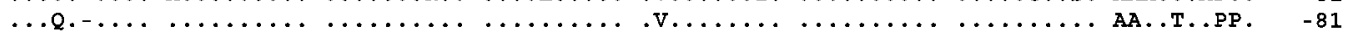

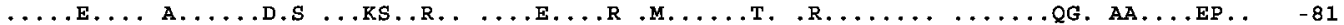

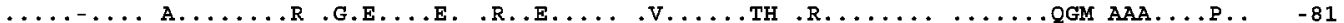

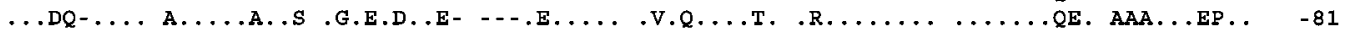

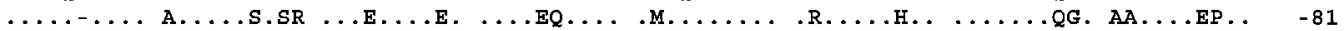

DLLVLSSGGP VAVPVSWGQG PPRWAVLHLA ASALPLLTHP VLALLLRCPL CTCSARPETM PFLVAHTRDR PPSAGERARR

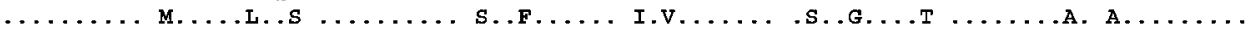

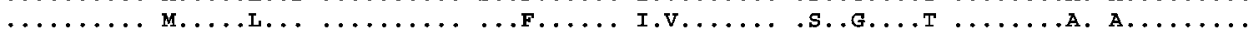

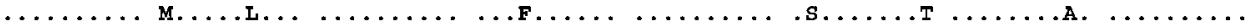

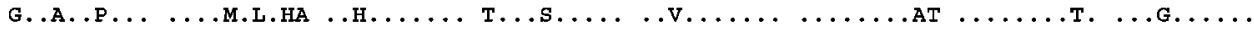
$\ldots$...R. . .

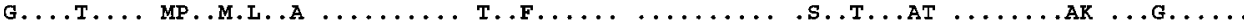

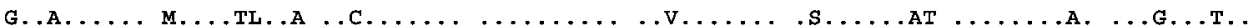

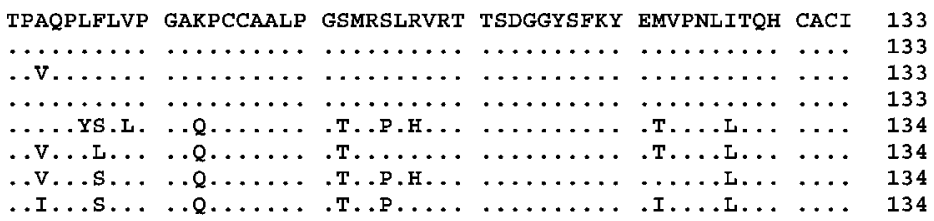

Figure 1 A comparison of the deduced amino-acid sequence of golden hamster (g. hamster) inhibin $\alpha$-subunit precursor with other species. Gene bank accession numbers of the protein sequences of rat, mouse, Siberian hamster (Phodopus sungorus, S. hamster), human, pig (porcine), cow (bovine) and horse (equine) are AAA41435, AAA39314, AF432351, 1608260A, WFPGA, P07994 and BAA08863 respectively. The first amino acid of the mature protein was numbered +1 . In Figs 1 to 3 , the positions of the first amino acids of mature golden hamster inhibin/activin subunits were determined according to the protein sequences of inhibin/activin subunits of other species. Identical amino-acid sequences are indicated by dots. Missing amino-acid residues are indicated by dashes.

complete open reading frame, which consists of 1101 nucleotides. Unfortunately, we could not obtain 5'-RACE products for either $\beta \mathrm{A}-$ or $\beta \mathrm{B}$-subunit. However, $3^{\prime}-$ RACE and usual PCR products revealed a $1.3 \mathrm{~kb}$ cDNA for $\beta A$-subunit that contained 1239 base protein coding region, and a $2 \cdot 8 \mathrm{~kb} c D N A$ for $\beta B$-subunit that contained 987 base protein coding region. A poly adenylation signal (AATAAA) was found in $\alpha$-subunit cDNA at 148 bases downstream from the stop codon, and in $\beta B$-subunit cDNA at 1789 bases downstream from the stop codon. However, consensus polyadenylation signal was not found in $\beta A$-subunit cDNA, suggesting that reverse transcription started from a short polyadenine sequence in the $3^{\prime}$-untranslated region of $\beta A$-subunit mRNA. Another possibility is that the $\beta A$-subunit mRNA has an atypical polyadenylation signal. The nucleic acid sequences of golden hamster inhibin/activin subunits are available from the DNA Data Base of Japan (DDBJ; Mishima, Shizuoka, Japan). The accession numbers are AB187511, AB187512 and $\mathrm{AB} 187513$ for $\alpha_{-}, \beta \mathrm{A}_{-}$and $\beta \mathrm{B}$-subunit $\mathrm{cDNAs}$ respectively. The deduced amino-acid sequences of golden hamster inhibin/activin subunits are shown in Figs 1 to 3 and compared with those of other mammalian species. The first N-terminus amino acid of the predicted mature form is numbered +1 . The golden hamster inhibin $\alpha$-subunit precursor consists of 366-amino-acid residues (Fig. 1) and the deduced amino-acid sequence shares $88 \cdot 8$, $88 \cdot 5,92 \cdot 9,78 \cdot 7,81 \cdot 4,78 \cdot 6$ and $80 \cdot 1 \%$ homology with those of rat (gene bank accession number: AAA41435), mouse (AAA39314), Siberian hamster (Phodopus sungorus) (AF432351), human (1608260A), pig (WFPGA), cow (P07994) and horse (BAA08863) respectively. 


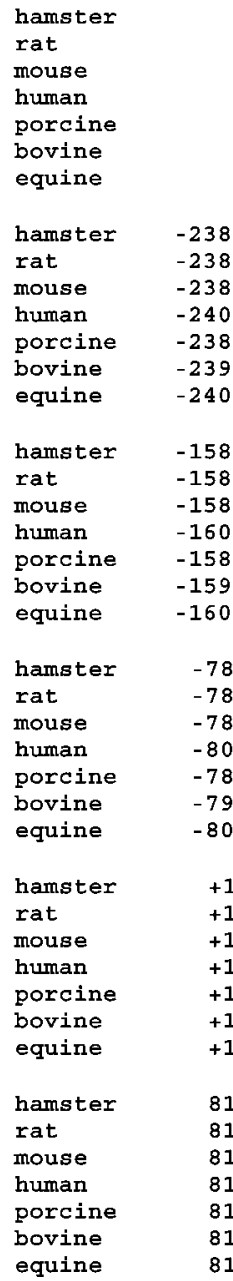

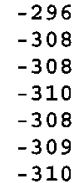

SCWIIVRS SPTPGSEGHG AAPDCPSCAL ATLPKDGPNS QPEMVEAVKK HILNMLHLKK

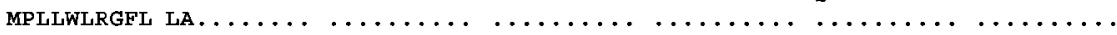

MPLLWLRGFL LA. ........... $\ldots \ldots \ldots \ldots \ldots \ldots \ldots \ldots \ldots \ldots \ldots$

MPLLWLRGFL LA. ........... $\ldots \ldots \ldots \ldots . . \ldots . \ldots \ldots \ldots$

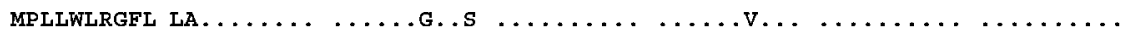

MPLLWLRGFL LA. ........... $\ldots \ldots \ldots \ldots, \ldots \ldots, \ldots \ldots \ldots$

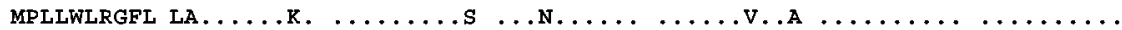

RPDVTQPVPK AALLNAIRKL HVGKVGENGY VEIEDDIGRR AEMNELMEQT SEIITFAESG TARKTLHFEI SKEGSDLSVV

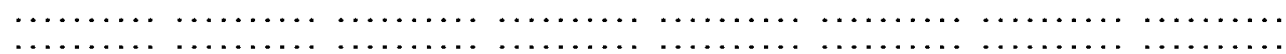

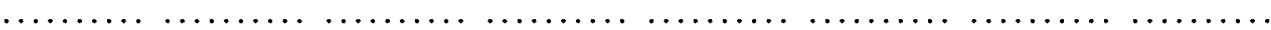

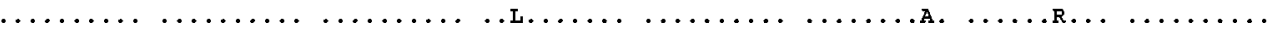

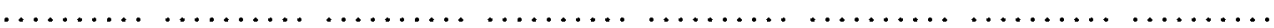

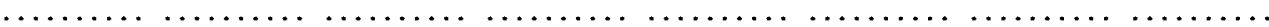

ERAEIWLFLK VPKANRTRTK VTIRLFQQQK HPQGSLDMGD EAEEMGLKGE RSELLLSEKV VDARKSTWHI FPVSSSIQRL

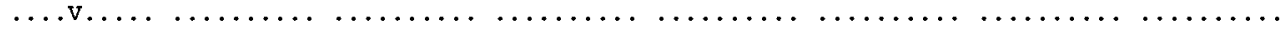

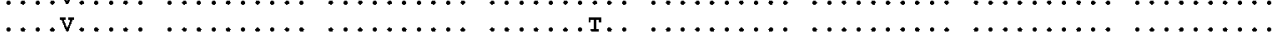

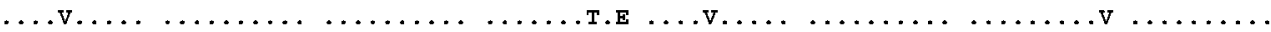

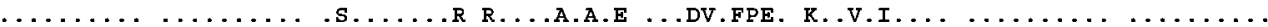

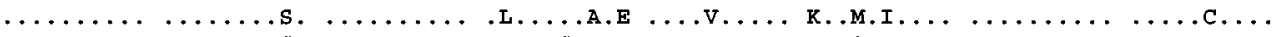

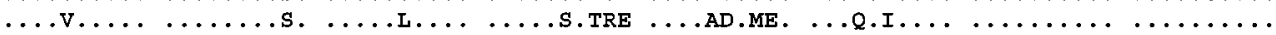

LDQGKSSLDV RIACEQCQES GASLVLLGKK KKKEVDGDGK KKEGSDGAA- -EEEKEQSHR PFLMLQARQS EDHPHRRRRR

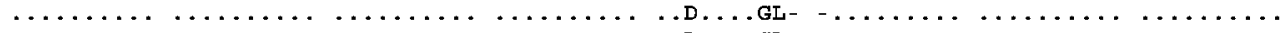

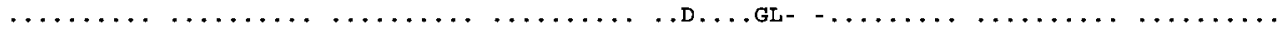

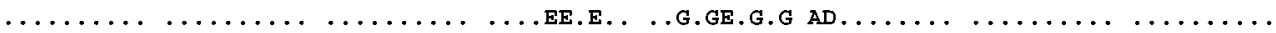

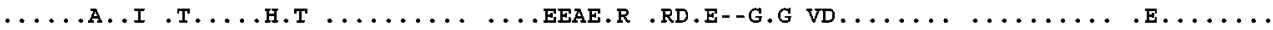

$\ldots \ldots \ldots$ I $\ldots \ldots \ldots$ T $\ldots \ldots \ldots \ldots \ldots$ EE.E. .RD.-E.G.G GD $\ldots \ldots \ldots \ldots \ldots \ldots \ldots \ldots$

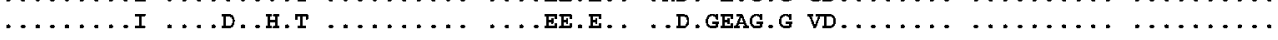

GLECDGKVNI CCKKQFFVSF KDIGWNDWII APSGYHANYC EGECPSHIAG TSGSSLSFHS TVINHYRMRG HSPFANLKSC

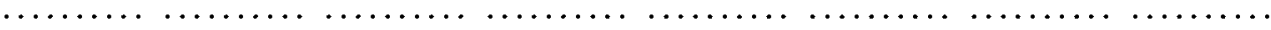

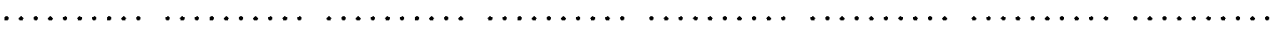

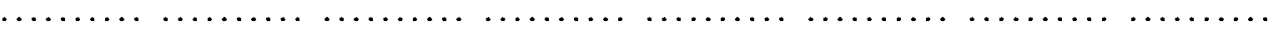

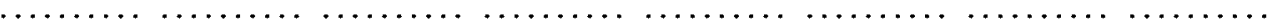

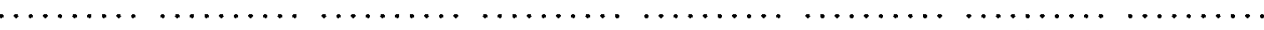

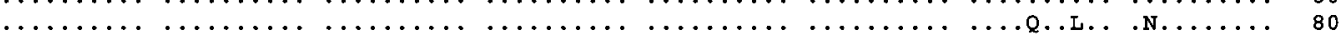

CVPTKLRPMS MLYYDDGQNI IKKDIQNMIV EECGCS 116

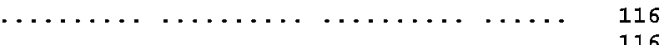

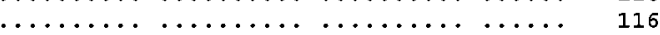

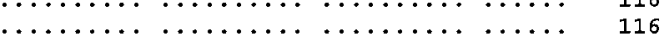

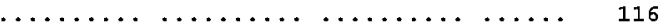

Figure 2 A comparison of the deduced amino-acid sequence of golden hamster inhibin $\beta A$-subunit with those of other mammalian species. Gene bank accession numbers of the protein sequences of rat, mouse, human, pig, cow and horse are AAA41436, CAA49325, AAA59168, NP_999193, P07995 and BAA08862 respectively. See Fig. 1 for details.

The amino-acid sequence of the predicted mature form of the golden hamster inhibin $\alpha$-subunit shares $94 \cdot 7,95 \cdot 5$, $95 \cdot 5,80 \cdot 6,85 \cdot 1,87 \cdot 3$ and $85 \cdot 8$ homology with those of rat, mouse, Siberian hamster, human, pig, cow and horse respectively. The golden hamster $\beta$ A-subunit cDNA revealed the partial amino-acid sequence of the $\beta$ A-subunit, which corresponded to the C-terminus 412amino-acid residues (Fig. 2). The partial protein sequence of the $\beta$ A-subunit shares $99 \cdot 0,98 \cdot 5,95 \cdot 4,90 \cdot 5,94 \cdot 4$ and 91.1\% homology with those of rat (AAA41436), mouse (CAA49325), human (AAA59168), pig (NP_999193), cow (P07995) and horse (BAA08862) respectively. The amino-acid sequence of the predicted mature form of the golden hamster $\beta$ A-subunit shares $100 \%$ homology with those of rat, mouse, human, pig and cow, and $97 \cdot 4 \%$ homology with that of the horse. The golden hamster $\beta B$-subunit cDNA revealed the partial amino-acid sequence of the $\beta \mathrm{B}$-subunit, which corresponded to
C-terminus 328-amino-acid residues (Fig. 3). The partial protein sequence of golden hamster $\beta \mathrm{B}$-subunit shares $99 \cdot 1,99 \cdot 1,96 \cdot 3,95 \cdot 7$ and $95 \cdot 1 \%$ homology with those of rat (B41398), mouse (P09529), human (AAA59451), pig (AAM66766) and cow (P42917) respectively. The aminoacid sequence of the predicted mature form of the golden hamster $\beta B$-subunit shares 100, 100, 96.5, $96 \cdot 5$ and $97 \cdot 4 \%$ homology with those of rat, mouse, human, pig and cow respectively.

Changes in inhibin/activin subunit $m R N A$ levels in the golden hamster ovary during the oestrous cycle

Levels of three inhibin/activin subunit mRNAs showed different changing patterns during the oestrous cycle (Fig. 4). Levels of $\alpha$-subunit mRNA in the ovary continuously increased from day 2 to the evening of day 4 and returned to the basal levels by $1100 \mathrm{~h}$ on day 1 . Levels of 


$\begin{array}{ll}\text { rat } & -296 \\ \text { mouse } & -296 \\ \text { human } & -292 \\ \text { porcine } & -292 \\ \text { bovine } & -293\end{array}$

MDGLPGR ALGAACLLIL AAGWLGPEAW GSPTPPPSPA AP-PPPPPPG APGGSODTCT MDGLPGR ALGAACLLLL VAGWLGPEAW GSPTPPPSPA AP-PPPPPPG APGGSQDTCT MDGLPGR ALGAACLLLL AAGWLGPEAW GSPTPPPTPA AQ-PPPPPPG SPGGSQDTCT MDGLPGR ALGAACLLLL AAGWLGPEAW GSPTPPPSPA AP-PPPPPPG ALGGSODTCT MDGLPGR ALGAACLLML AVGSLGPGVW GSPTPPPLPA APQPPPPPPG APGGSQDTCT
$-241$

$-241$

$-237$

237

$-237$

\begin{tabular}{|c|c|c|c|c|c|c|c|c|c|c|}
\hline hamster & -213 & & & RHI & LNRLQLRGRP & NITHAVPKAA & MVTALRKLFA & GKVREDGRVE & IPHLDGHASP & -16 \\
\hline rat & -240 & SCGGGGGGFR & RPEELGRVDG & DFLEAVK . . &.$s \ldots \ldots$. & $\ldots \ldots \ldots$ & & & $\ldots \ldots \ldots$ & \\
\hline mouse & -240 & SCGGGGGGFR & RPEELGRVDG & DFLEAVK... & $. s \ldots . .$. & $\cdots$ & & $\cdots$ & & \\
\hline human & -236 & SCGG--- - FR & RPEELGRVDG & DFLEAVK... & . S...M... & $\ldots \ldots \ldots$ & $\ldots \ldots \ldots$ & $\ldots \ldots \ldots$ & $\cdots$ & \\
\hline porcine & -236 & SCGG--- - FR & RPEELGRLDG & DFLEAVK. . . & $\ldots$..... & $\ldots \ldots \ldots$ & $\cdots \ldots \ldots$ & $\cdots \ldots \ldots$ & $\cdots$ & \\
\hline bovine & -236 & SCGG--- - FR & RPEELGRVDG & DFLEAVK. . . & ....M.... & $\ldots \ldots \ldots \ldots$ & $\ldots \ldots \ldots$ & $\ldots \ldots \ldots \ldots$ & & \\
\hline
\end{tabular}

\begin{tabular}{|c|c|c|c|c|c|c|c|c|c|c|}
\hline er & 160 & GADGQERVSE & IISFAETDGL & ASSRVRLYFF & VSNEGNQNLF & VVQASLWLYL & KLLPYVLEKG & SRRKVRVKVY & YQEQGHGDRW & -81 \\
\hline at & -160 & $\ldots \ldots \ldots$ & $\ldots \ldots \ldots$ & $\ldots \ldots \ldots$ & $\ldots \ldots \ldots$ & $\ldots \ldots \ldots$ & $\ldots \ldots \ldots$ & $\ldots \ldots \ldots$ & F...... & -81 \\
\hline & -160 & $\cdots \ldots \ldots$ & $\cdots \cdots \ldots$ & $\ldots \ldots \ldots$ & & $\ldots \ldots \ldots$ & & & & -81 \\
\hline & -160 & $\ldots \ldots \ldots$ & $\cdots \ldots \ldots$ & $\ldots \ldots \ldots$ & $I \ldots \ldots$ & $\cdots \cdots$ & $\cdots$ & $\cdots$ & F. . & -81 \\
\hline & -160 & $\ldots \ldots \ldots$ & $\ldots \ldots \ldots$ & $\ldots \ldots \ldots \ldots$ & $I \ldots \ldots \ldots$ & $\ldots \ldots \ldots$ & $\ldots \ldots$ & $\cdots$ & F...P. & -81 \\
\hline
\end{tabular}

\begin{tabular}{|c|c|c|c|c|c|c|}
\hline hamster & -80 & SVVEKKVDLK & RSGWHTFPIT & EAIQALFERG & \multicolumn{2}{|c|}{ ERRLNLDVQC } \\
\hline rat & -80 & N........ & $\ldots \ldots \ldots$ & $\ldots \ldots \ldots$ & \multirow{2}{*}{\multicolumn{2}{|c|}{$\ldots \ldots \ldots$}} \\
\hline mouse & -80 & N........ & $\ldots \ldots \ldots$ & $\ldots \ldots \ldots$ & & $\ldots \ldots \ldots$ \\
\hline human & -80 & NM...R... & ........ & $\ldots \ldots \ldots$ & \multicolumn{2}{|c|}{$\cdots \ldots \ldots$} \\
\hline porcine & -80 & D...R... & ........L. & $\ldots \ldots \ldots$ & \multicolumn{2}{|c|}{$\cdots \ldots \ldots$} \\
\hline ovine & -80 & AA $\ldots$ R. . & $\ldots \ldots \ldots$ I. & . P....S. & \multicolumn{2}{|c|}{$\ldots$. } \\
\hline hamster & +1 & GLECDGRTSL & CCRQQFFIDF & RLIGWNDWII & \multicolumn{2}{|c|}{ APTGYYGNYC } \\
\hline rat & +1 & $\ldots \ldots \ldots$ & $\ldots \ldots \ldots$ & $\ldots \ldots \ldots$ & \multicolumn{2}{|c|}{$\ldots \ldots \ldots$} \\
\hline nouse & +1 & $\ldots \ldots \ldots$ & $\cdots \ldots \ldots$ & $\ldots \ldots \ldots$ & \multicolumn{2}{|c|}{$\cdots \cdots \cdots$} \\
\hline human & +1 & $\ldots \ldots \ldots$ N. & $\ldots \ldots$ & $\ldots \ldots \ldots$ & \multicolumn{2}{|c|}{$\ldots s \ldots \ldots$} \\
\hline porcine & +1 & $\ldots \ldots \ldots$ N. & $\ldots \ldots \ldots$ & $\ldots$..... & \multicolumn{2}{|c|}{$\ldots \ldots \ldots$} \\
\hline oovine & +1 & $\ldots \ldots \ldots$ N. & $\ldots \ldots \ldots$ & $\ldots \ldots \ldots$ & \multicolumn{2}{|c|}{$\ldots \ldots \ldots$} \\
\hline hamster & 81 & IPTKLSSMSM & LYFDDEYNIV & KRDVPNMIVE & ECGCA & 115 \\
\hline at & 81 & $\cdots \cdots \cdots$ & $\ldots \ldots \ldots$ & $\ldots \ldots \ldots$ & $\ldots$ & 115 \\
\hline use & 81 & $\ldots \ldots \ldots$ & $\cdots \cdots \cdots$ & $\ldots \ldots \ldots$ & $\ldots$ & 115 \\
\hline man & 81 & $\ldots \ldots$. . . & $\ldots \ldots \ldots$ & $\ldots \ldots \ldots$ & $\ldots \ldots$ & 115 \\
\hline rcine & 81 & $\ldots \ldots \mathbf{T} \ldots$ & $\ldots \ldots \ldots$ & $\ldots \ldots \ldots$ & $\ldots \ldots$ & 115 \\
\hline ovine & 81 & $\ldots \ldots \mathbf{T}, \ldots$ & $\ldots \ldots \ldots$ & $\ldots \ldots$ & $\ldots \ldots$ & 115 \\
\hline
\end{tabular}

Figure 3 A comparison of the deduced amino-acid sequence of golden hamster inhibin $\beta B$-subunit with those of other mammalian species. Gene bank accession numbers of the protein sequences of rat, mouse, human, pig and cow are B41398, P09529, AAA59451, AAM66766 and P42917 respectively. See Fig. 1 for details.

$\beta A$-subunit mRNA remained low from day 1 to the morning of day 4. At $1700 \mathrm{~h}$ on day 4, levels of $\beta A$-subunit mRNA showed a remarkable increase. Levels of $\beta B$-subunit mRNA remained at relatively high levels from day 2 to the morning of day 4, considerably decreased in the evening of day 4 , and recovered by the morning of day 1 . The changing patterns of plasma inhibins during the 4-day oestrous cycle of the golden hamster in our colony, which have been reported previously (Ohshima et al. 1999), are shown in Fig. 5 for comparison. The changing patterns of $\alpha-, \beta \mathrm{A}_{-}$and $\beta \mathrm{B}_{-}$ subunit mRNAs are similar to those of plasma inhibin pro- $\alpha \mathrm{C}$, inhibin $\mathrm{A}$ and inhibin $\mathrm{B}$ respectively.

Changes in localization of inhibin/activin subunit $m R N A s$ in the golden hamster ovary during the oestrous cycle

The following terminology was used to describe the stages of follicle maturation: primary follicle, an oocyte was surrounded by one to several layers of granulosa cells (up to $150 \mu \mathrm{m}$ ); secondary follicle, the maturing oocyte increases in size and becomes surrounded by more granulosa cell layers $(150-250 \mu \mathrm{m})$; tertiary follicle, this follicle is characterized by a fluid-filled antrum $(>250 \mu \mathrm{m})$. Some of the large tertiary follicles (up to $600 \mu \mathrm{m}$ ) will be selected for ovulation in the early morning of day 1 while others will undergo atretic processes. Preovulatory follicles can be distinguished from non-ovulatory large tertiary follicles on a histological basis, in which case changes in various cells types and structures surrounding the basal lamina can be observed.

Representative photographs of in situ hybridization are shown in Fig. 6. Strong signals for $\alpha$-subunit mRNA were detected in granulosa cells of large secondary $(>200 \mu \mathrm{m})$ and tertiary follicles throughout the oestrous cycle (Fig. 6). $\alpha$-Subunit mRNA was also found in granulosa cells of primary and small secondary $(<200 \mu \mathrm{m})$ follicles on each day of the oestrous cycle, and in luteal cells on days 1, 2 (Fig. 6i) and 3. However, the signals were weak as 


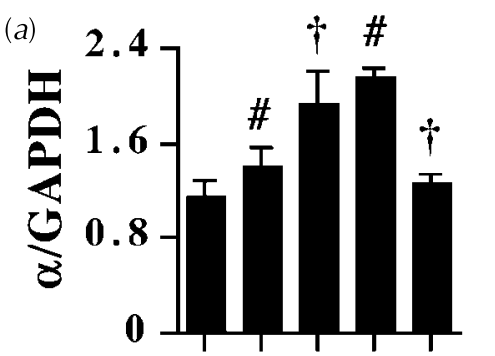

(b)
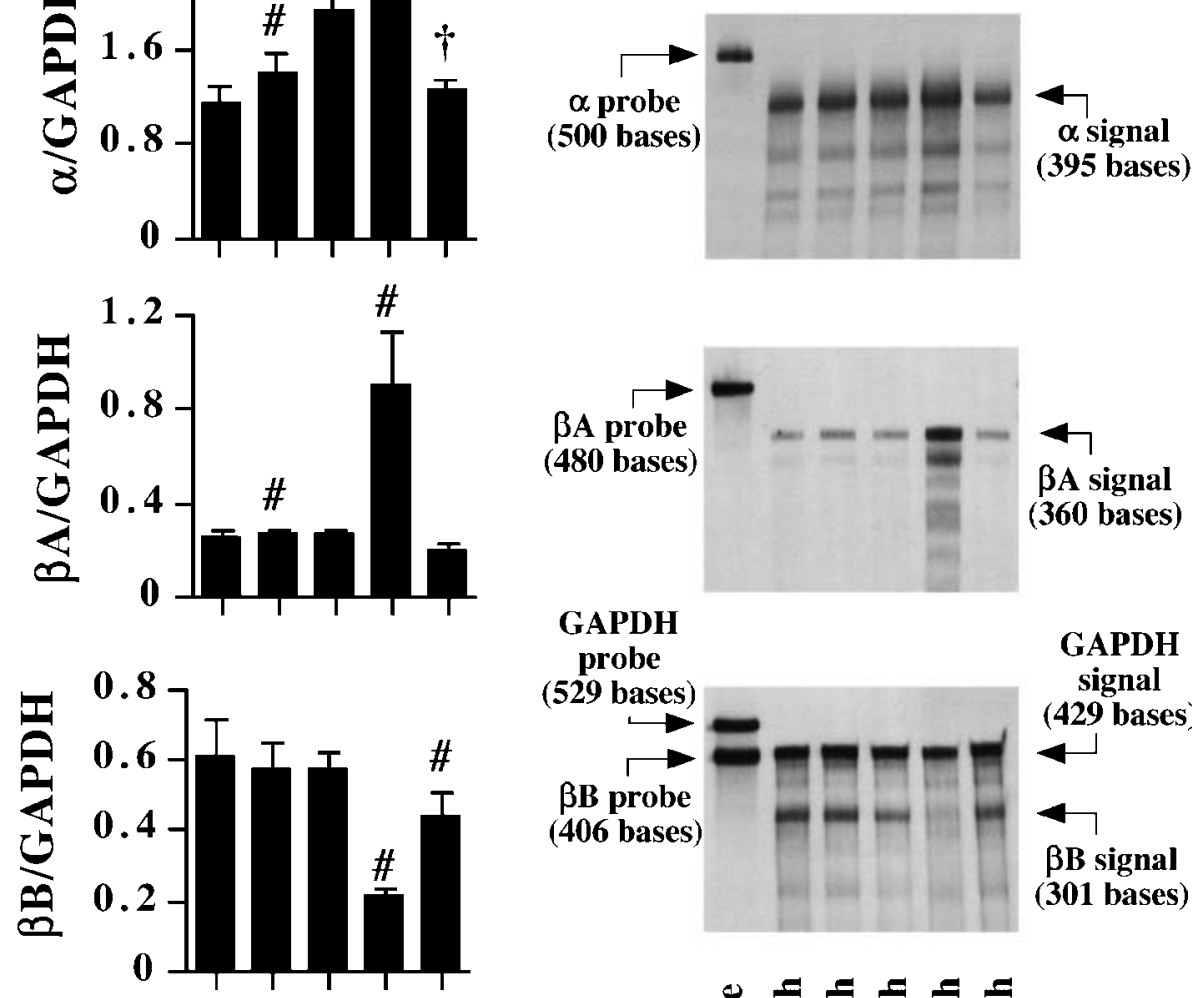

GAPDH

probe

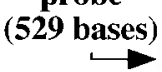

GAPDH

signal

(429 bases)

$\beta B$ probe

(406 bases)

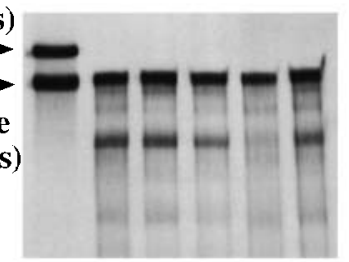

$\leftarrow$

$\beta B$ signal

(301 bases)

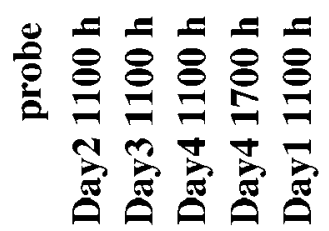

Figure 4 (a) Changes in inhibin/activin subunit mRNA levels in the golden hamster ovary during the oestrous cycle; mRNAs levels were examined by ribonuclease protection assays. The signals were analyzed with $\mathrm{NIH}$ image and results are expressed as intensity relative to GAPDH mRNA. Values are means \pm S.E.M. for three independent experiments. Bars with the same marks represent the minimum difference between values required for the points to be significantly different $(P<0 \cdot 05)$. (b) Representative images of ribonuclease protection assays detecting $\alpha-, \beta A$ - and $\beta B$-subunit mRNAs and GAPDH mRNA.

compared with large secondary and tertiary follicles. In the evening of day 4 , signals for $\alpha$-subunit mRNA were also detected in theca interna cells of tertiary and atretic follicles and in ovarian interstitial cells (Fig. 6f and k). Moderate signals for $\alpha$-subunit mRNA were detected in granulosa cells of atretic follicles throughout the oestrous cycle, while signals for $\beta \mathrm{A}$ - and $\beta \mathrm{B}$-subunit mRNAs were absent. The intensity of the signals for $\alpha$-subunit mRNA in atretic follicles was negatively correlated with the progress of atresia. $\beta A$-subunit mRNA was found in granulosa cells of large secondary and tertiary follicles throughout the oestrous cycle. It was also expressed in some small secondary follicles. Interestingly, $\beta A$-subunit
mRNA was found in ovarian interstitial cells and in theca interna cells of tertiary and atretic follicles in the evening of day 4 (Fig. 6f and 1). This distribution pattern of $\beta A$-subunit mRNA was not found in other species. $\beta \mathrm{B}$-subunit mRNA was localized in granulosa cells of large secondary, tertiary and some small secondary follicles throughout the oestrous cycle. Expression of $\beta \mathrm{B}$-subunit mRNA in tertiary follicles decreased from the morning of day 3 to the morning of day 4 (Fig. $6 \mathrm{~d}$ and e). The decrease in $\beta \mathrm{B}$-subunit mRNA in tertiary follicles started from peripheral granulosa cells. Expression of $\beta B$-subunit mRNA in tertiary follicles was very low in the evening of day 4 , while the strongest expression of $\alpha$ - and $\beta A$-subunit 
inhibin A

- inhibin B

$$
\text { inhibin pro- } \alpha \mathrm{C}
$$

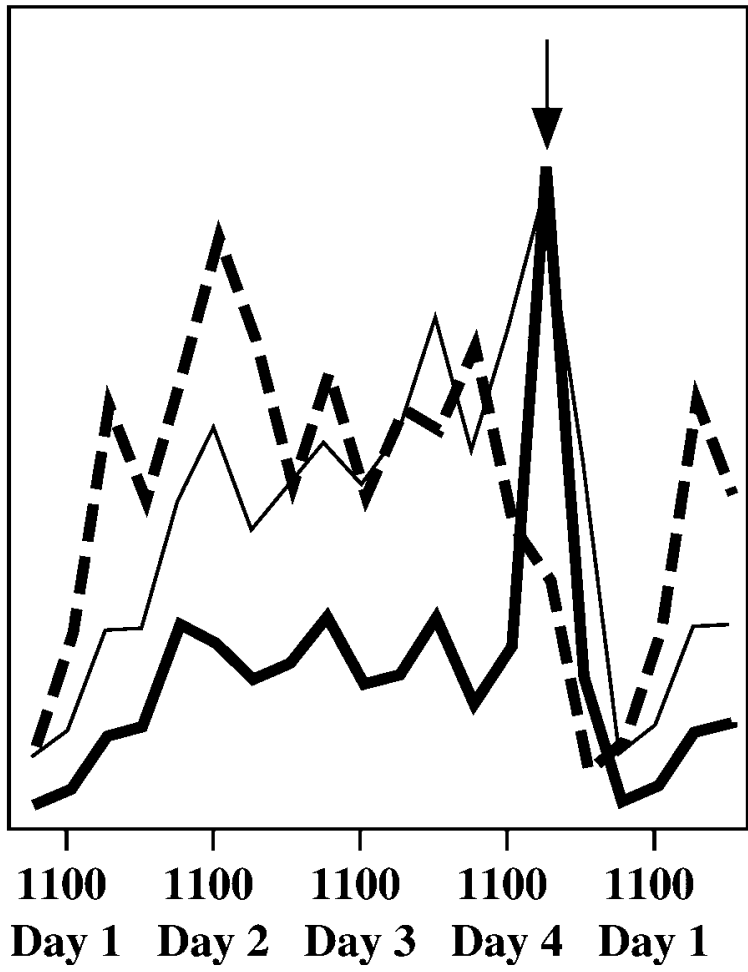

\section{Time and stage of the estrous cycle}

Figure 5 Changing patterns of circulating inhibin A, inhibin B and inhibin pro- $\alpha \mathrm{C}$ during the 4-day oestrous cycle of the golden hamster. These data are from a previously published report (Ohshima et al. 1999). The arrow indicates the time when the primary gonadotropin surge occurs (1700 h on day 4$)$.

mRNAs was observed in tertiary follicles at this time (Fig. 6f). At $2300 \mathrm{~h}$ on day 4, only $\alpha$-subunit mRNA was moderately expressed in preovulatory follicles (Fig. $6 \mathrm{~g}$ ). The relative abundance of inhibin/activin subunit mRNAs in granulosa cells of various follicles is summarized in Table 2.
Effects of anti-LHRH serum on levels of ovarian inhibin/activin subunit $m R N A$ s during the preovulatory period

The effects of anti-LHRH serum on ovarian inhibin/ activin subunit mRNA levels are shown in Fig. 7. RNA samples of intact animals at 1100 and $1700 \mathrm{~h}$ on day 4 were also examined for comparison. Administration of the anti-LHRH serum completely blocked the preovulatory rise of $\beta \mathrm{A}$ - and the preovulatory decrease in $\beta \mathrm{B}$-subunit mRNA levels (Fig. 7). Furthermore, an injection of hCG after the administration of the anti-LHRH serum partially restored the preovulatory increase in $\beta A$-subunit mRNA. In addition, the hCG treatment could decrease $\beta B$-subunit mRNA levels. These results strongly indicate that the preovulatory LH surge induces the striking rise in $\beta A$-subunit mRNA and the noticeable decrease in $\beta \mathrm{B}$-subunit mRNA at $1700 \mathrm{~h}$ on day 4 . On the other hand, the administration of anti-LHRH serum tended to decrease $\alpha$-subunit mRNA levels, and the hCG treatment moderately increased $\alpha$-subunit mRNA.

Effects of anti-LHRH serum on localization of ovarian inhibin/activin subunit $m R N A$ s during the preovulatory period

Administration of anti-LHRH serum at $1100 \mathrm{~h}$ on day 4 abolished the expression of $\alpha$ - and $\beta A$-subunit mRNAs in theca interna and ovarian interstitial cells at $1700 \mathrm{~h}$ on day 4 (Fig. 8a). In contrast, an injection of hCG, which followed the administration of anti-LHRH serum, restored $\alpha$ - and $\beta A$-subunit mRNA expression in theca interna and ovarian interstitial cells (Fig. 8c and e). With respect to $\beta B$-subunit mRNA, it was still detected in tertiary follicles of the animals treated with anti-LHRH serum alone (Fig. 8a), while it was abolished by an injection of hCG that followed the treatment with anti-LHRH serum (Fig. 8c).

\section{Discussion}

The present study is the first to demonstrate deduced amino-acid sequences of golden hamster inhibin/activin subunits and changing patterns of inhibin/activin subunit mRNAs in the golden hamster ovary during the oestrous cycle.

The primary structures of golden hamster inhibin/ activin subunits confirmed that amino-acid sequences of

Figure 6 Localization of $\alpha$-, $\beta A$ - and $\beta B$-subunit mRNAs in the golden hamster ovary during the oestrous cycle. Serial sections were hybridized to $\alpha$-, $\beta$ A- and $\beta B$-antisense probes. At each stage, one of the serial sections was stained with haematoxylin and eosin in order to check the morphology of the follicles (data not shown). (a) $0500 \mathrm{~h}$ on day 1 (oestrus); (b) 1100 on day 1 ; (c) $1100 \mathrm{~h}$ on day 2 (metoestrus); (d) $1100 \mathrm{~h}$ on day 3 (dioestrus); (e) $1100 \mathrm{~h}$ on day 4 (pro-oestrus); (f) $1700 \mathrm{~h}$ on day 4 ; (g) $2300 \mathrm{~h}$ on day 4 . Representative negative control sections ( $1700 \mathrm{~h}$ on day 4 ) hybridized with sense probes are also shown in column $\mathrm{h}$. ( $\mathrm{i}$ and $\mathrm{j}) \mathrm{A}$ corpus luteum at $1100 \mathrm{~h}$ on day 2 hybridized with $\alpha$-antisense probe (i) or $\alpha$-sense probe (j). (k and I) High magnification of the sections in column f. P, primary follicle; S, secondary follicle; T, tertiary follicle; PO, preovulatory follicle; $\mathrm{A}$, atretic follicle; $\mathrm{CL}$, corpus luteum; $\mathrm{TI}$, theca interna cells; I, interstitium. Scale bars indicate $200 \mu \mathrm{m}$. Although only representative negative control sections were shown, negative control hybridization was done for all stages. The results were very similar to the sections in column $\mathrm{h}$. 

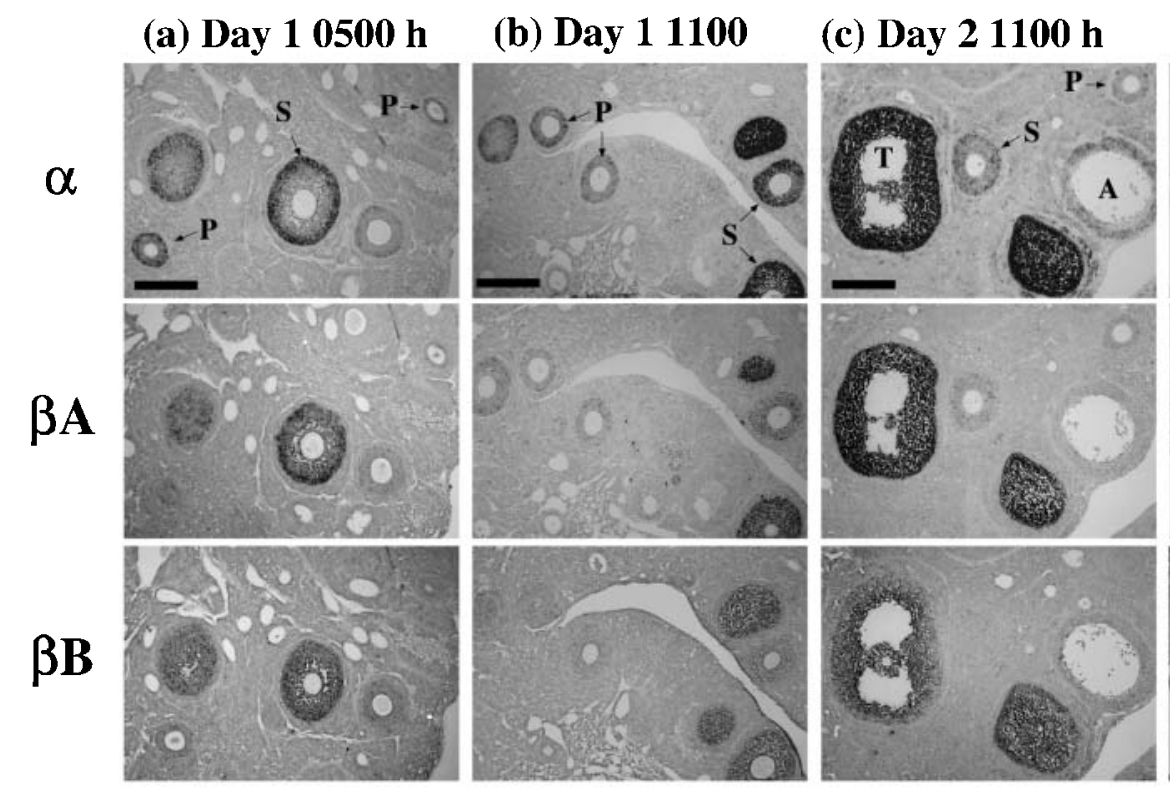

(d) Day $31100 \mathrm{~h}$
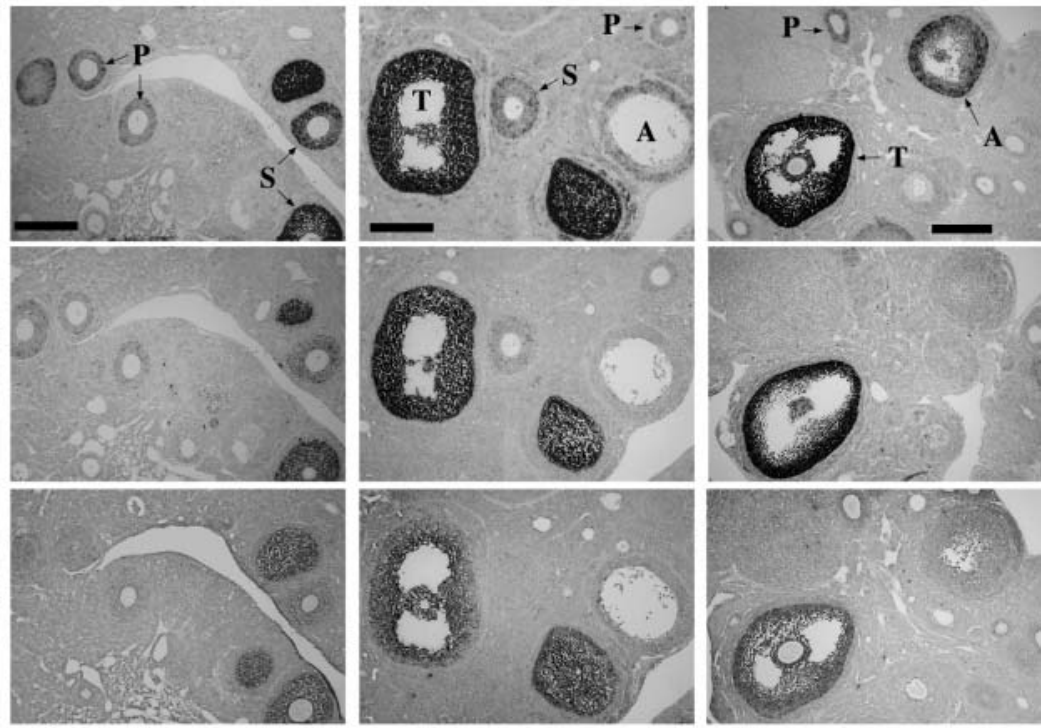

(e) Day $41100 \mathrm{~h}$

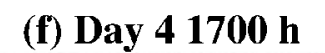

(g) Day $42300 \mathrm{~h}$
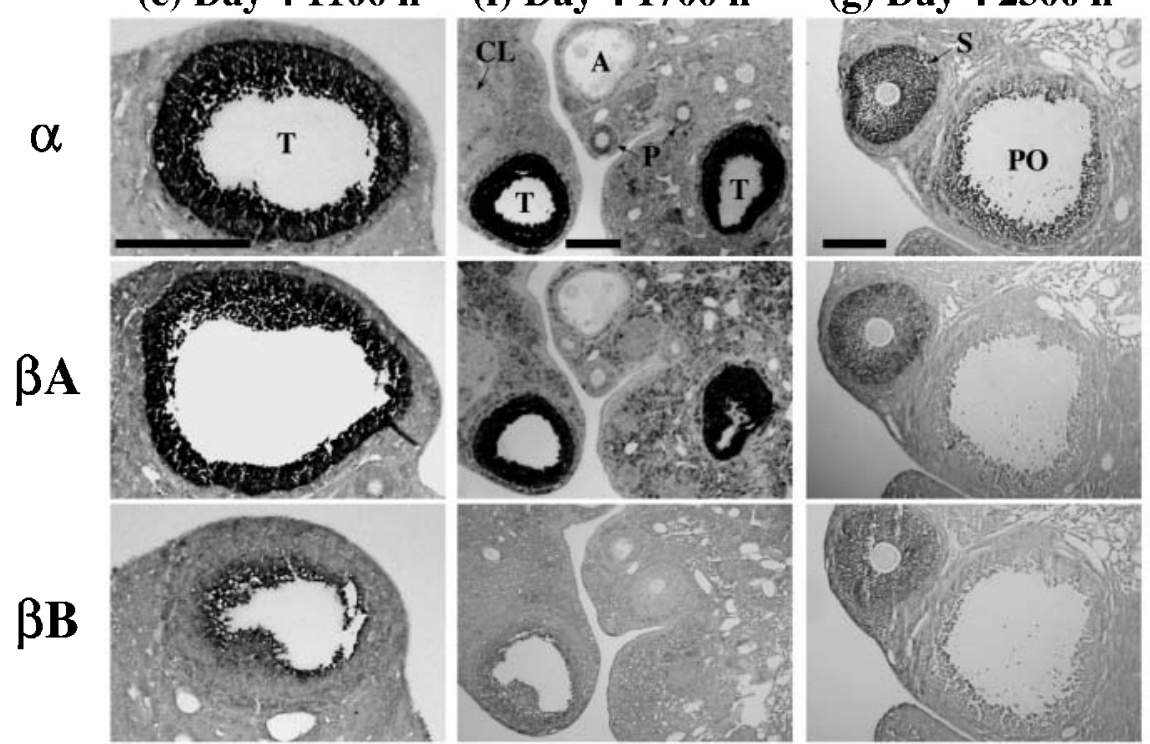

(h)

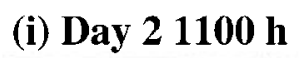

(j)

(k) Day 41700 h
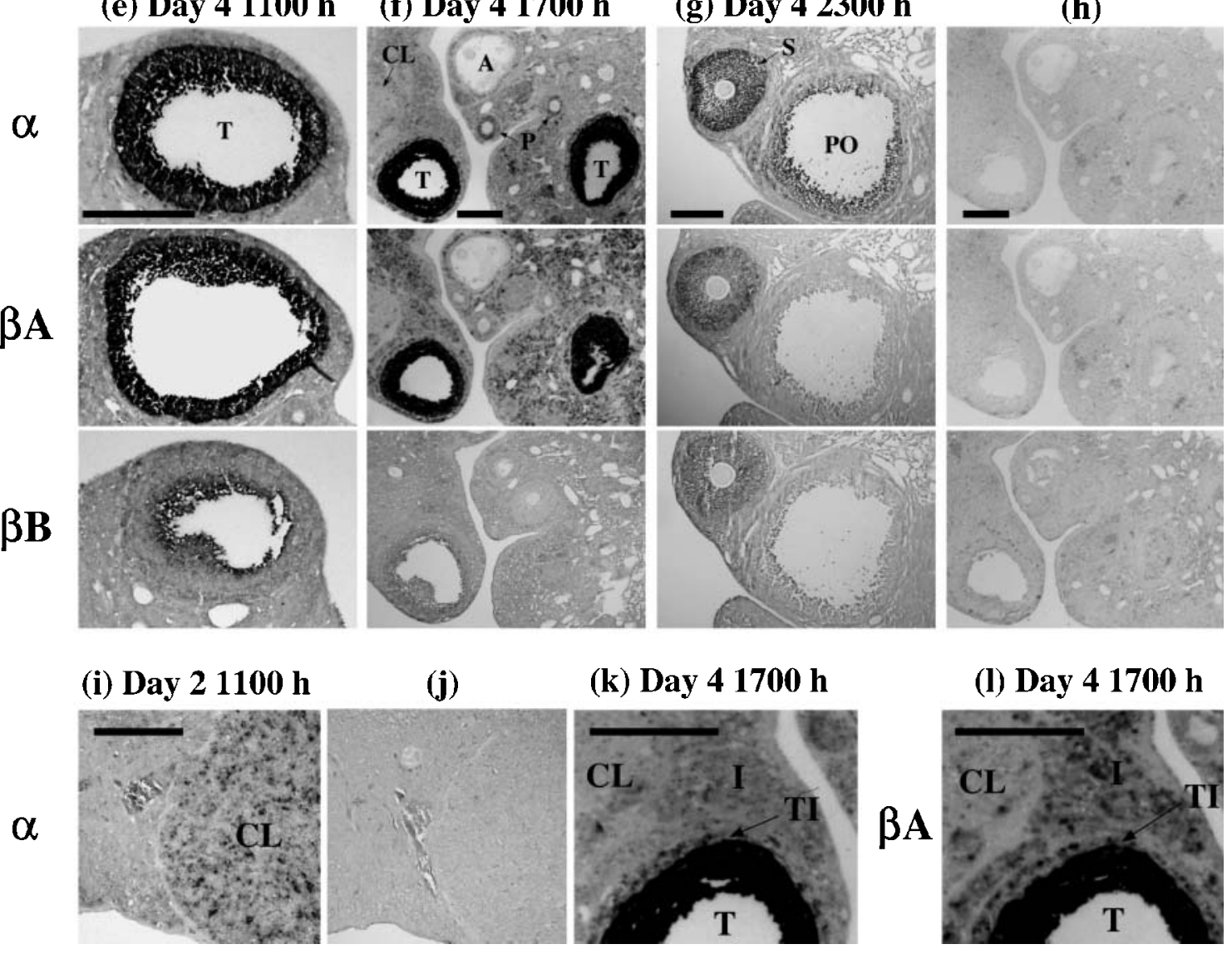
Table 2 Relative abundance of inhibin/activin subunit mRNAs in granulosa cells of various follicles in the golden hamster ovary during the oestrous cycle. Sections from at least three animals were examined at each sampling point

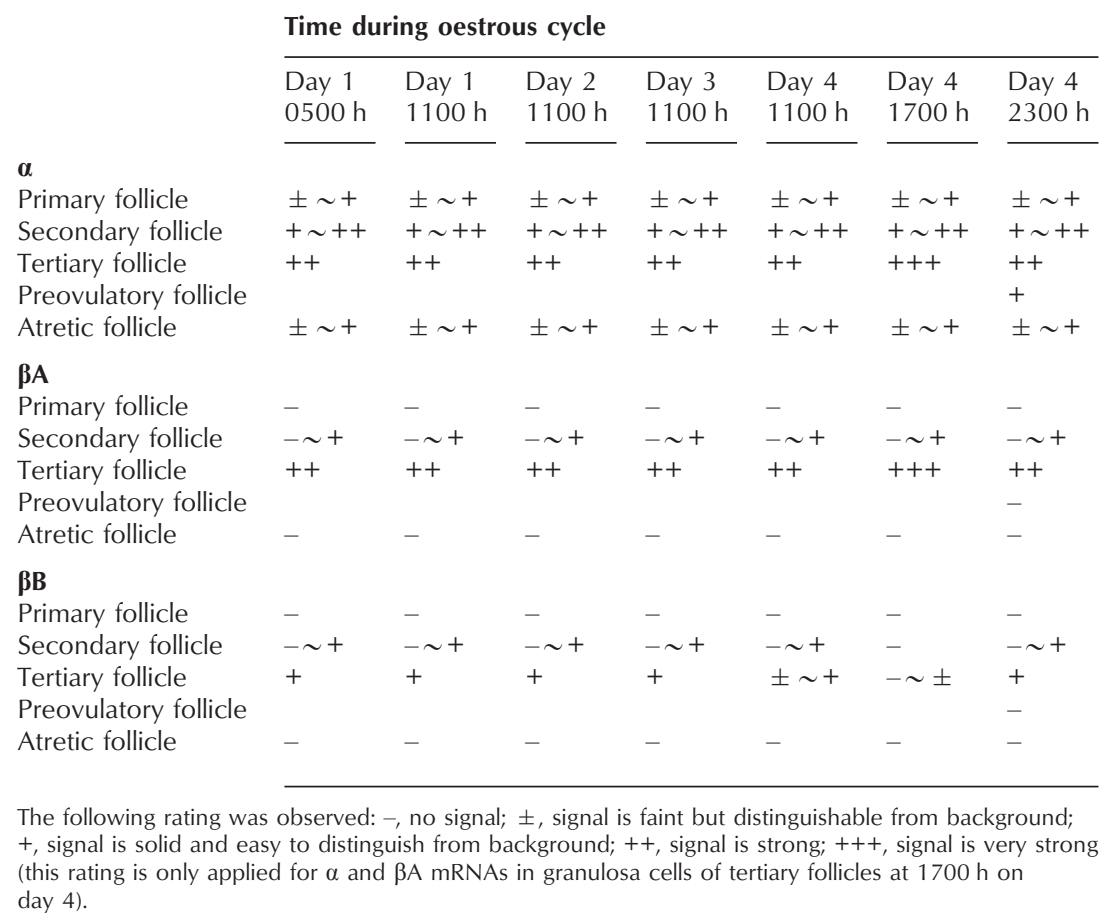

$\alpha$-subunits are rather diverse between species, as compared with those of $\beta$-subunits. In particular, mature forms of golden hamster, rat, mouse, human, porcine and bovine $\beta$ A-subunits show $100 \%$ identity, indicating that conservation of the amino-acid sequence of the $\beta A$-subunit is very important for its function. Northern-blot hybridization using ovarian total RNA detected: 1.5 and $3.4 \mathrm{~kb} \alpha$ transcripts; $1.3,1.5$ and $6.2 \mathrm{~kb} \beta A$ transcripts; and 1.5 and $3.4 \mathrm{~kb} \beta \mathrm{B}$ transcripts (data not shown). The variation in size of inhibin/activin subunit mRNAs has been shown in other species (Mason et al. 1985, Esch et al. 1987, Woodruff et al. 1987, Chen \& Johnson 1996, Yamanouchi et al. 1997). According to the sizes of the PCR products, $\alpha$ - and $\beta B$-subunit cDNAs that we have obtained are probably 1.5 and $3.4 \mathrm{~kb}$ in length respectively. The full size of the $\beta A$-subunit cDNA that we have cloned is not known because we did not find the consensus polyadenylation signal in the $\beta A$-subunit cDNA.

The distribution pattern of $\alpha$-subunit mRNA in the golden hamster ovary is consistent with previous observations in the rat (Meunier et al. 1988). Because expression of $\alpha$-subunit mRNA in granulosa cells increased as follicles developed, the increase in ovarian $\alpha$-subunit mRNA levels during the follicular phase is probably due to development of large follicles to be selected for ovulation. However, previous studies indicated that in the golden hamster, the ovary of day 3 was most abundant in healthy large follicles, and the number of healthy large follicles decreased from day 3 to the morning of day 4 (Greenwald 1991, Kishi et al. 1995). Therefore, $\alpha$-subunit mRNA levels do not reflect merely the number of large healthy follicles. Because considerable levels of $\alpha$-subunit mRNA were detected in early atretic follicles, it may be responsible for the discordance between $\alpha$-subunit mRNA levels and the number of large healthy follicles. $\alpha$-Subunit mRNA was also found in ovarian interstitial cells and theca interna cells during the preovulatory period, as observed in the rat ovary (Meunier et al. 1988, Rivier et al. 1989). Involvement of the LH surge in the regulation of thecal and interstitial $\alpha$-subunit mRNA expression is also consistent with the results in the rat (Rivier et al. 1989). Expression of $\alpha$-subunit mRNA in these types of cells may partly contribute to the increase in $\alpha$-subunit mRNA in the evening of day 4.

The expression pattern of $\beta A$-subunit mRNA in granulosa cells of the golden hamster ovary is consistent with a previous study in the rat (Meunier et al. 1988). However, in the golden hamster, $\beta A$-subunit mRNA was also expressed in ovarian interstitial cells and theca interna cells in response to the LH surge or administration of hCG. This distribution pattern of $\beta$ A-subunit mRNA has not been observed in the rat or in other species. 

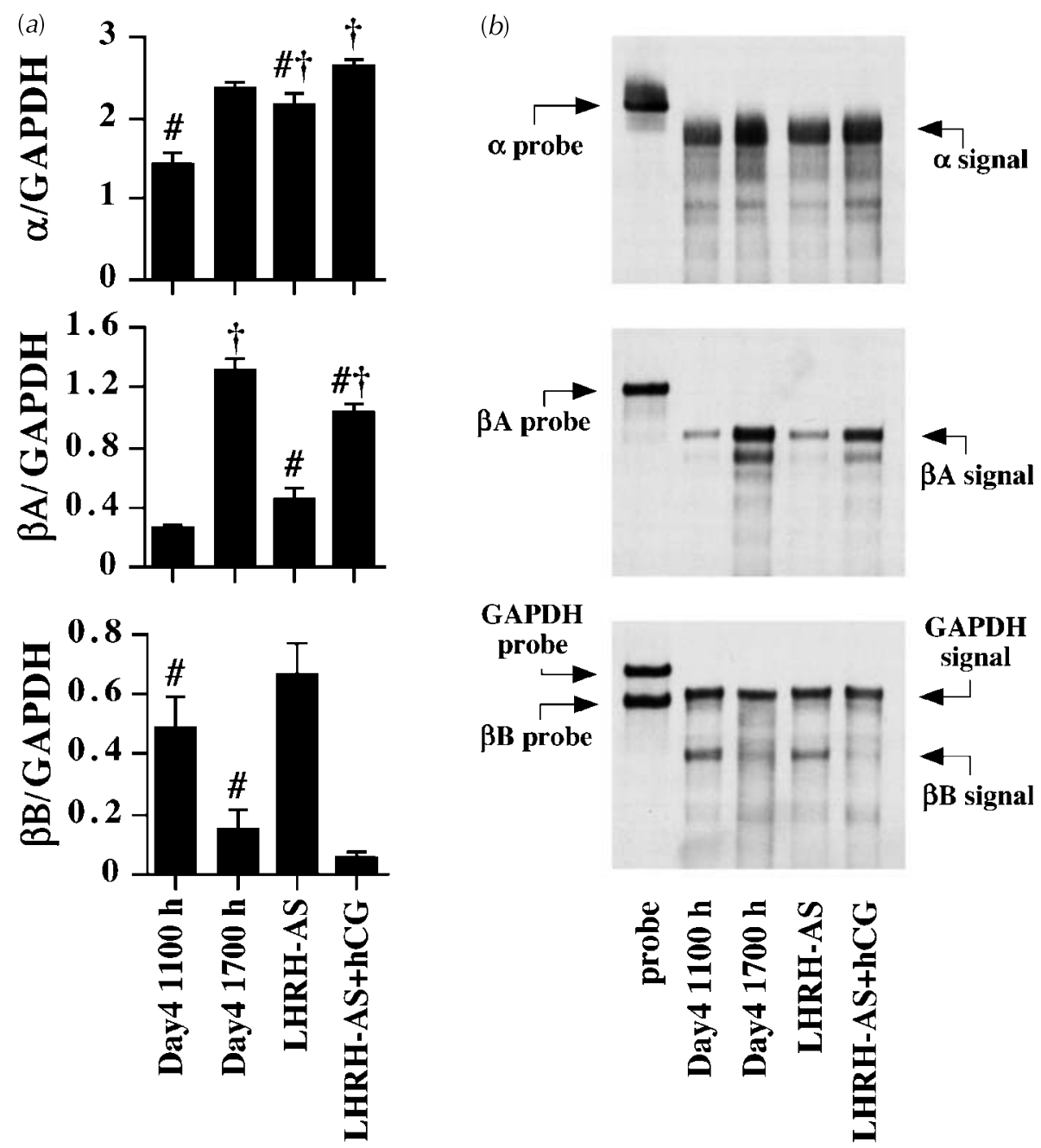

Figure 7 (a) Effects of anti-LHRH serum on levels of ovarian inhibin/activin subunit mRNAs during the preovulatory period. Animals were given an i.v. injection of $200 \mu \mathrm{l}$ anti-LHRH serum at $1100 \mathrm{~h}$ on day 4. Thereafter, the animals received an i.v. injection of either saline (LHRH-AS) or $10 \mathrm{IU}$ hCG (LHRH-AS+hCG) at $1300 \mathrm{~h}$. They were killed at $1700 \mathrm{~h}$ on day 4 and ovarian total RNA samples were collected. mRNA levels were examined by ribonuclease protection assays. Samples obtained from intact animals at 1100 and $1700 \mathrm{~h}$ on day 4 were also examined for comparison. The signals were analyzed with $\mathrm{NIH}$ image and results are expressed as intensity relative to GAPDH mRNA. Values are means \pm S.E.M. for three independent experiments. Bars with the same marks represent the minimum difference between values required for the points to be significantly different $(P<0 \cdot 05)$. (b) Representative images of ribonuclease protection assays detecting $\alpha-, \beta A-$ and $\beta B$-subunit mRNAs and GAPDH mRNA.

Furthermore, the golden hamster ovary expressed noticeably high levels of $\beta A$-subunit mRNA during the preovulatory period, which was not observed in the rat (Arai et al. 2002). A previous study has shown that there are LH/hCG binding sites in the interstitial tissue of the golden hamster ovary (Oxberry \& Greenwald 1982), indicating that $\mathrm{LH}$ directly affects ovarian interstitial cells to induce expression of $\alpha-$ and $\beta A$-subunit mRNAs. Since the strongest signals for $\beta A$-subunit mRNA during the oestrous cycle were found in granulosa cells of tertiary follicles at this time, the increase in $\beta A$-subunit expression in large follicles was probably a cause of the abrupt increase in $\beta A$-subunit mRNA levels. Furthermore, the expression of $\beta A$-subunit mRNA in ovarian interstitial cells may also contribute to the increase in $\beta A$-subunit mRNA levels since the interstitial tissue occupies a large area in the ovary. It is likely that the preovulatory rise in $\beta A$-subunit mRNA preferentially increased activin $A$ secretion because 


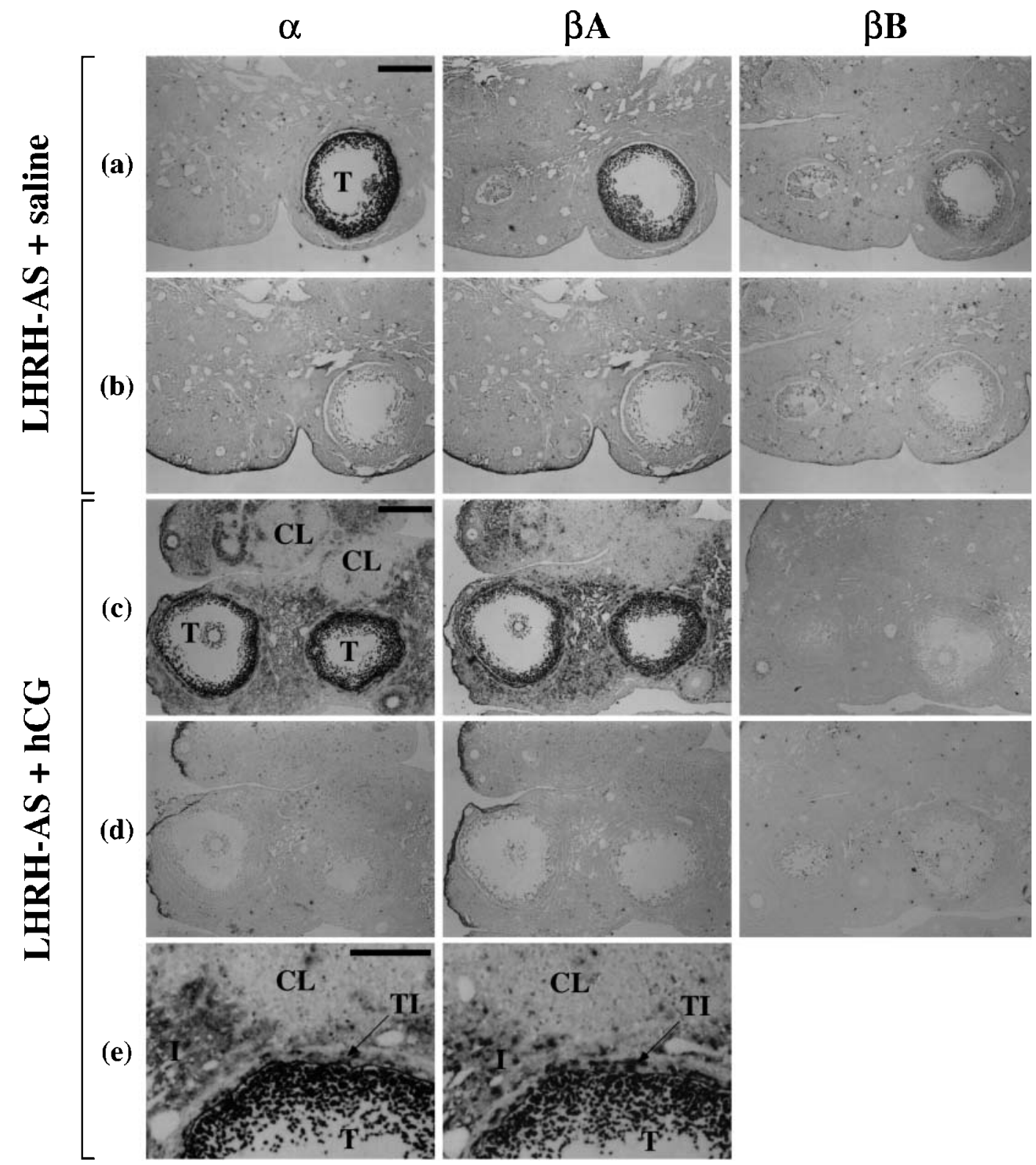

Figure 8 Effects of anti-LHRH serum on localization of inhibin/activin subunit mRNAs during the preovulatory period. Animals were given an i.v. injection of $200 \mu \mathrm{l}$ anti-LHRH serum at $1100 \mathrm{~h}$ on day 4 . Thereafter, the animals received an i.v. injection of either saline (LHRH-AS + saline) or $10 \mathrm{IU}$ hCG (LHRH-AS + hCG) at 1300 h. Ovaries were collected at $1700 \mathrm{~h}$ on day 4 . Serial sections were hybridized to $\alpha-, \beta A$ - and $\beta B$-antisense probes. One of the serial sections was stained with haematoxylin and eosin in order to check the morphology of the follicles (data not shown). ( $a$ and c) Sections hybridized with antisense probes; (b and d) negative control sections hybridized with sense probes; (e) high magnification of row c. T, tertiary follicle; $\mathrm{CL}$, corpus luteum; $\mathrm{Tl}$, theca interna cells; I, interstitium. Scale bars indicate either $200 \mu \mathrm{m}$ (rows a-d) or $100 \mu \mathrm{m}$ (row e). The sections are representative of three independent experiments.

$\alpha$-subunit mRNA did not show noticeable increase as compared with $\beta A$-subunit mRNA. The increase in $\beta A$-subunit mRNA may have some roles in the regulation of follicular development because activin affects functions of ovarian cells (Hillier \& Miro 1993, Findlay et al. 2001).
In addition, the increase in $\beta A$-subunit mRNA may be responsible for the low levels of plasma progesterone in the golden hamster (Kishi et al. 1995) as compared with the rat (Watanabe et al. 1991) because activin is known to suppress progesterone secretion from both granulosa 
(Shukovski \& Findlay 1990, Li et al. 1992) and luteal cells (Brannian et al. 1992, Di Simone et al. 1994).

Throughout the oestrous cycle, the changing pattern of $\beta \mathrm{B}$-subunit mRNA in the golden hamster ovary is consistent with that in the rat (Meunier et al. 1988, Arai et al. 2002). As observed in the rat (Meunier et al. 1988), $\beta \mathrm{B}$-subunit mRNA in tertiary follicles decreased as maturation of follicles advanced, whereas that of $\beta A$-subunit mRNA remained high until the evening of day 4 . The decrease in $\beta B$-subunit mRNA in tertiary follicles started from peripheral granulosa cells, indicating that there are physiological differences between inner and outer layer of granulosa cells in large tertiary follicles. Results of both in situ hybridization and ribonuclase protection assay revealed a noticeable decrease in ovarian $\beta \mathrm{B}$-subunit mRNA levels in the evening of day 4 and the experiments using anti-LHRH serum clearly indicate that the LH surge induced the preovulatory decrease in $\beta B$-subunit mRNA. This abrupt decrease in $\beta B$-subunit mRNA may be important for triggering the secondary FSH surge and subsequent recruitment of developing follicles.

The changing patterns of ovarian $\beta \mathrm{A}$ - and $\beta \mathrm{B}$-subunit mRNAs in this study were very similar to those of circulating inhibin A and inhibin B (Ohshima et al. 1999) respectively. In particular, the abrupt increase in $\beta A$ subunit mRNA is in agreement with the noticeable increase in plasma concentrations of inhibin $\mathrm{A}$ in the evening of day 4 that is characteristic in the golden hamster. The preovulatory increase in inhibin A may be responsible for the clear separation of the primary and secondary FSH surges in this species (Bast \& Greenwald 1974, Kishi et al. 1995).

Previous studies have shown that both inhibin and activin affect steroidogenesis of theca cells (Hillier et al. 1991a, 1991b), suggesting that inhibin A and activin A of theca interna origin may regulate steroid secretion by theca cells via autocrine or paracrine fashion during preovulatory period, i.e., the LH surge may modulate steroid secretion by theca cells through induction of inhibin $\mathrm{A}$ and activin A secretion in addition to the direct effects of $\mathrm{LH}$.

In the present study, $\alpha$-subunit mRNA was found in corpora lutea while $\beta \mathrm{A}$ - and $\beta \mathrm{B}$-subunit mRNAs had already disappeared from preovulatory follicles at $2300 \mathrm{~h}$ on day 4. Similarly, follicles, which undergo atresia, expressed only $\alpha$-subunit mRNA. These results suggest that the transcription of $\alpha$-subunit mRNA is sustained longer than that of $\beta A$ - and $\beta B$-subunit mRNAs during differentiation from granulosa cells to luteal cells or during atretic processes. Because either $\beta \mathrm{A}$ - or $\beta \mathrm{B}$-subunit is required to secrete biologically active dimers, strict regulation of $\alpha$-subunit mRNA may not necessary. It is also possible that the $\alpha$-subunit monomer has some physiological roles through unknown biological activities.

In summary, the present study revealed the primary structures of inhibin/activin subunits of the golden hamster, the unique expression pattern of $\beta$ A-subunit mRNA in the golden hamster ovary and its induction by the preovulatory LH surge. The unique expression pattern of $\beta A$-subunit mRNA may be a cause of some of the unique reproductive features of the female golden hamster.

\section{Acknowlegements}

We are grateful to Atsushi Fukuda for the care and treatment of the hamsters.

\section{Funding}

This work was supported in part by the Ito foundation (to K Y A) and a Grant-in-Aid for Scientific Research (The 21st Century Center-of-Excellence Program, E-1) from the Ministry of Education, Culture, Sports, Science and Technology of Japan (to K T). The authors declare that there is no conflict of interest that would prejudice the impartiality of this scientific work.

\section{References}

Arai K, Watanabe G, Taya K \& Sasamoto S 1996 Roles of inhibin and estradiol in the regulation of follicle-stimulating hormone and luteinizing hormone secretion during the estrous cycle of the rat. Biology of Reproduction 55 127-133.

Arai K, Komura H, Akikusa T, Iio K, Kishi H, Watanabe G \& Taya K 1997 Contributions of endogenous inhibin and estradiol to the regulation of follicle-stimulating hormone and luteinizing hormone secretion in the pregnant rat. Biology of Reproduction 56 1482-1489.

Arai KY, Watanabe G, Arai K, Uehara K \& Taya K 2001 Contribution of endogenous inhibin to the decline of the secondary surge of follicle-stimulating hormone in the rat. Reproduction, Fertility and Development 13 203-209.

Arai KY, Ohshima K, Watanabe G, Arai K, Uehara K \& Taya K 2002 Dynamics of messenger RNAs encoding inhibin/activin subunits and follistatin in the ovary during the rat estrous cycle. Biology of Reproduction 66 1119-1126.

Arai KY, Tsuchida K, Uehara K, Taya K \& Sugino H 2003 Characterization of rat follistatin-related gene (FLRG): effects of estrous cycle stage and pregnancy on its mRNA expression in rat reproductive tissues. Biology of Reproduction 68 199-206.

Bast JD \& Greenwald GS 1974 Serum profiles of follicle-stimulating hormone, luteinizing hormone and prolactin during the estrous cycle of the hamster. Endocrinology 94 1295-1299.

Brannian JD, Woodruff TK, Mather JP \& Stouffer RL 1992 Activin-A inhibits progesterone production by macaque luteal cells in culture. Journal of Clinical Endocrinology and Metabolism 75 756-761.

Chen CC \& Johnson PA 1996 Expression of inhibin $\alpha$ and inhibin/activin $\beta A$ subunits in the granulosa layer of the large preovulatory follicles of the hen. Biology of Reproduction 55 450-454.

Culler MD \& Negro-Vilar A 1989 Endogenous inhibin suppresses only basal follicle-stimulating hormone secretion but suppresses all parameters of pulsatile luteinizing hormone secretion in the diestrous female rat. Endocrinology 124 2944-2953.

Di Simone N, Lanzone A, Petraglia F, Ronsisvalle E, Caruso A \& Mancuso S 1994 Effect of activin-A on progesterone synthesis in human luteal cells. Fertility and Sterility 62 1157-1161. 
Engelhardt H, Smith KB, McNeilly AS \& Baird DT 1993 Expression of messenger ribonucleic acid for inhibin subunits and ovarian secretion of inhibin and estradiol at various stages of the sheep estrous cycle. Biology of Reproduction 49 281-294.

Esch FS, Shimasaki S, Cooksey K, Mercado M, Mason AJ, Ying SY, Ueno N \& Ling N 1987 Complementary deoxyribonucleic acid (cDNA) cloning and DNA sequence analysis of rat ovarian inhibins. Molecular Endocrinology 1 388-396.

Findlay JK, Drummond AE, Dyson M, Baillie AJ, Robertson DM \& Ethier JF 2001 Production and actions of inhibin and activin during folliculogenesis in the rat. Molecular and Cellular Endocrinology 180 139-144.

Grady KL \& Greenwald GS 1968 Gonadotropic induction of pseudopregnancy in the cyclic hamster. Endocrinology 83 1173-1180.

Greenwald GS 1991 Quantitative study of follicular development in the ovary of the intact or unilaterally ovariectomized hamster. Journal of Reproduction and Fertility 2 351-361.

Hillier SG \& Miro F 1993 Inhibin, activin, and follistatin. Potential roles in ovarian physiology. Annuls of the New York Academy of Sciences 687 29-38.

Hillier SG, Yong EL, Illingworth PJ, Baird DT, Schwall RH \& Mason AJ 1991a Effect of recombinant inhibin on androgen synthesis in cultured human thecal cells. Molecular and Cellular Endocrinology 75 R1-6.

Hillier SG, Yong EL, Illingworth PJ, Baird DT, Schwall RH \& Mason AJ $1991 b$ Effect of recombinant activin on androgen synthesis in cultured human thecal cells. Journal of Clinical Endocrinology and Metabolism 72 1206-1211.

de Jong FH 1988 Inhibin Physiological Reviews 68 555-607.

Kaneko H, Nakanishi Y, Akagi S, Arai K, Taya K, Watanabe G, Sasamoto S \& Hasegawa Y 1995 Immunoneutralization of inhibin and estradiol during the follicular phase of the estrous cycle in cows. Biology of Reproduction 53 931-939.

Kaneko H, Noguchi J, Kikuchi K, Todoroki J \& Hasegawa Y 2002 Alterations in peripheral concentrations of inhibin A in cattle studied using a time-resolved immunofluorometric assay: relationship with estradiol and follicle-stimulating hormone in various reproductive conditions. Biology of Reproduction 67 38-45.

Kenny HA, Bernard DJ, Horton TH \& Woodruff TK 2002a Photoperiod-dependent regulation of inhibin in Siberian hamsters: I. Ovarian inhibin production and secretion. Journal of Endocrinology 174 71-83.

Kenny HA, Bernard DJ, Horton TH \& Woodruff TK $2002 b$ Photoperiod-dependent regulation of inhibin in Siberian hamsters: II. Regulation of inhibin production and secretion by pregnant mare serum gonadotropin. Journal of Endocrinology 174 85-94.

Kishi H, Taya K, Watanabe G \& Sasamoto S 1995 Follicular dynamics and secretion of inhibin and oestradiol- $17 \beta$ during the oestrous cycle of the hamster. Journal of Endocrinology 146 169-176.

Kishi H, Itoh M, Ohshima K, Wang MW, Watanabe G \& Taya K 1999 Regulation of gonadotropin secretion by circulating inhibin, estradiol, and progesterone in cyclic hamsters. American Journal of Physiology - Endocrinology and Metabolism 277 E876-E882.

Kishi H, Ohshima K, Itoh M, Tsukada J, Arai KY, Nakano S, Watanabe G \& Taya K 2002 Changes in expression of inhibin subunits in the cyclic golden hamster (Mesocricetus auratus) and the regulation of inhibin $\alpha$ subunit production by luteinizing hormone. Zoological Science 19 225-232.

Li W, Yuen BH \& Leung PC 1992 Inhibition of progestin accumulation by activin-A in human granulosa cells. Journal of Clinical Endocrinology and Metabolism 75 285-289.

Mason AJ, Hayflick JS, Ling N, Esch F, Ueno N, Ying SY, Guillemin R, Niall H \& Seeburg PH 1985 Complementary DNA sequences of ovarian follicular fluid inhibin show precursor structure and homology with transforming growth factor- $\beta$. Nature 318 659-663.
Mather JP, Woodruff TK \& Krummen LA 1992 Paracrine regulation of reproductive function by inhibin and activin. Proceedings of the Society for Experimental Biology and Medicine 201 1-15.

Mather JP, Moore A \& Li RH 1997 Activins, inhibins, and follistatins: further thoughts on a growing family of regulators. Proceedings of the Society for Experimental Biology and Medicine 215 209-222.

Medan MS, Watanabe G, Sasaki K, Nagura Y, Sakaime H, Fujita M, Sharawy S \& Taya K 2003 Effects of passive immunization of goats against inhibin on follicular development, hormone profile and ovulation rate. Reproduction 125 751-757.

Merchenthaler I, Culler MD, Petrusz P \& Negro-Vilar A 1987 Immunocytochemical localization of inhibin in rat and human reproductive tissues. Molecular and Cellular Endocrinology 54 239-243.

Meunier H, Cajander SB, Roberts VJ, Rivier C, Sawchenko PE, Hsueh AJ \& Vale W 1988 Rapid changes in the expression of inhibin $\alpha-, \beta \mathrm{A}-$, and $\beta \mathrm{B}$-subunits in ovarian cell types during the rat estrous cycle. Molecular Endocrinology 2 1352-1363.

Muttukrishna S, Fowler PA, Groome NP, Mitchell GG, Robertson WR \& Knight PG 1994 Serum concentrations of dimeric inhibin during the spontaneous human menstrual cycle and after treatment with exogenous gonadotrophin. Human Reproduction 9 1634-1642.

Ohshima K, Kishi H, Ito M, Watanabe G, Arai K, Uehara K, Groome NP \& Taya K 1999 Secretion of inhibin A, inhibin B and inhibin pro- $\alpha \mathrm{C}$ during the oestrous cycle of the golden hamster (Mesocricetus auratus). Journal of Endocrinology 162 451-456.

Oxberry BA \& Greenwald GS 1982 An autoradiographic study of the binding of ${ }^{125}$ I-labeled follicle-stimulating hormone, human chorionic gonadotropin and prolactin to the hamster ovary throughout the estrous cycle. Biology of Reproduction 27 505-516.

Rivier C \& Vale W 1989 Immunoneutralization of endogenous inhibin modifies hormone secretion and ovulation rate in the rat. Endocrinology 125 152-157.

Rivier C, Rivier J, \& Vale W 1986 Inhibin-mediated feedback control of follicle-stimulating hormone secretion in the female rat. Science 234 205-208.

Rivier C, Roberts V \& Vale W 1989 Possible role of luteinizing hormone and follicle-stimulating hormone in modulating inhibin secretion and expression during the estrous cycle of the rat. Endocrinology 125 876-882.

Rokukawa S, Inoue K, Miyamoto K, Kurosumi K \& Igarashi M 1986 Immunohistochemical localization of inhibin in porcine and bovine ovaries. Archivum Histologicum Japonicum 49 603-611.

Schwall RH, Mason AJ, Wilcox JN, Bassett SG \& Zeleznik AJ 1990 Localization of inhibin/activin subunit mRNAs within the primate ovary. Molecular Endocrinology 4 75-79.

Shukovski L \& Findlay JK 1990 Activin-A inhibits oxytocin and progesterone production by preovulatory bovine granulosa cells in vitro. Endocrinology 126 2222-2224.

Taya K, Kishi H, Arai K, Otsuka M \& Watanabe G 1996 Inhibin in the regulation of FSH secretion and folliculogenesis in rats and hamsters. Journal of Reproduction and Development 42 Suppl $28-30$.

Watanabe G, Taya K \& Sasamoto S 1990 Dynamics of ovarian inhibin secretion during the oestrous cycle of the rat. Journal of Endocrinology 126 151-157.

Woodruff TK, Meunier H, Jones PB, Hsueh AJ \& Mayo KE 1987 Rat inhibin: molecular cloning of $\alpha$ - and $\beta$-subunit complementary deoxyribonucleic acids and expression in the ovary. Molecular Endocrinology 1 561-568.

Woodruff TK, D’Agostino J, Schwartz NB \& Mayo KE 1988 Dynamic changes in inhibin messenger RNAs in rat ovarian follicles during the reproductive cycle. Science 239 1296-1299.

Woodruff TK, Besecke LM, Groome N, Draper LB, Schwartz NB \& Weiss J 1996 Inhibin A and inhibin B are inversely correlated to follicle-stimulating hormone, yet are discordant during the follicular 
phase of the rat estrous cycle, and inhibin A is expressed in a sexually dimorphic manner. Endocrinology 137 5463-5467.

Yamanouchi K, Hirasawa K, Hasegawa T, Ikeda A, Chang KT, Matsuyama S, Nishihara M, Miyazawa K, Sawasaki T, Tojo H, Tachi C \& Takahashi M 1997 Equine inhibin/activin $\beta A$-subunit mRNA is expressed in the endometrial gland, but not in the trophoblast, during pregnancy. Molecular Reproduction and Development 47 363-369.
Ying S-Y 1988 Inhibins, activins, and follistatins: gonadal proteins modulating the secretion of follicle-stimulating hormone. Endocrine Reviews 9 267-293.

Received 4 January 2005

Accepted 24 February 2005 